NASACONTRACTOR REPOR T

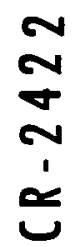

$$
\begin{aligned}
& \frac{\pi}{2}
\end{aligned}
$$

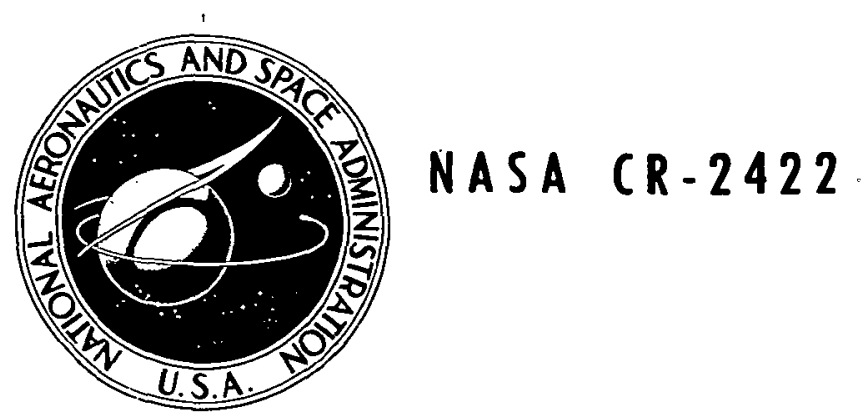

\title{
THE EFFECT OF YTTRIUM AND THORIUM ON THE OXIDATION BEHAVIOR \\ OF Ni-Cr-Al ALLOYS
}

by Arun Kumar, M. Nasrallah, and D. L. Douglass

Prepared by

UNIVERSITY OF CALIFORNIA

Los Angeles, Calif.

for Ames Research Center

National aeronautics and SPACE administration - WAShIngton, D. C. • may 1974 


\begin{tabular}{|c|c|c|}
\hline $\begin{array}{l}\text { 1. Report No. } \\
\text { NASA CR-2422 }\end{array}$ & 2. Government Accession No. & 3. Recipient's Catalog No. \\
\hline \multirow{2}{*}{\multicolumn{2}{|c|}{$\begin{array}{l}\text { 4. Title and Subtitle } \\
\text { THE EFFECT OF YTTRIUM AND THORIUM ON THE OXIDATION BEHAVIOR OF } \\
\text { Ni-Cr-Al ALLOYS }\end{array}$}} & $\begin{array}{l}\text { 5. Report Date } \\
\text { MAY } 1974\end{array}$ \\
\hline & & 6. Performing Organization Code \\
\hline \multirow{2}{*}{\multicolumn{2}{|c|}{$\begin{array}{l}\text { 7. Author(s) } \\
\text { Arun Kumar, M. Nasrallah and D. L. Douglass }\end{array}$}} & 8. Performing Organization Report No. \\
\hline & & \\
\hline \multirow{3}{*}{\multicolumn{2}{|c|}{$\begin{array}{l}\text { 9. Performing Organization Name and Address } \\
\text { University of California } \\
\text { School of Engineering \& Applied Science } \\
\text { Los Angeles, California }\end{array}$}} & \\
\hline & & $\begin{array}{l}\text { 11. Contract or Grant No. } \\
\text { NGR } 05-007-352\end{array}$ \\
\hline & & 13. Type of Report and Period Covered \\
\hline \multirow{2}{*}{\multicolumn{2}{|c|}{$\begin{array}{l}\text { 12. Sponsoring Agency Name and Address } \\
\text { National Aeronautics \& Space Administration } \\
\text { Washington, D.C. } 20546\end{array}$}} & Interim Summary Report \\
\hline & & 14. Sponsoring Agency Code \\
\hline
\end{tabular}

15. Supplementary Notes

16. Abstract

The effect of quaternary additions of $0.5 \% \mathrm{Y}, 0.5$ and $1.0 \%$ Th to a base alloy of $\mathrm{Ni}-10 \mathrm{Cr}-5 \mathrm{Al}$ on the oxidation behavior and mechanism was studied during oxidation in air over the range of 1000 to $1200^{\circ} \mathrm{C}$. The presence of yttrium decreased the oxidation kinetics slightly, whereas, the addition of thorium caused a slight increase. Oxide scale adherence was markedly improved by the addition of the quaternary elements.

Although a number of oxides formed on yttrium-containing alloys, quantitative $X$-ray diffraction clearly showed that the rate-controlling step was the diffusion of aluminum through shortcircuit paths in a thin layer of alumina that formed parabolically with time. Mixed oxides containing both aluninum and yttrium formed by the reaction of $\mathrm{Y}_{2} \mathrm{O}_{3}$ to form $\mathrm{YAlO}_{3}$ initally, and $\mathrm{Y}_{3} \mathrm{Al}_{5} \mathrm{O}_{12}$ ( $\mathrm{YAG}$ ) after longer times. Although the scale adherence of the yttrium-containing alloy was considerably better than the base alloys, spalling did occur that was attributed to the formation of the voluminous YAG particles which grew in a "mushroom"-1ike manner, lifting the protective scale off the substrate locally. The YAG particles formed primarily at grain boundaries in the substrate in which the yttrium originally existed as $\mathrm{YNi}_{9}$. This intermetallic compound reacted to form $\mathrm{Y}_{2} \mathrm{O}_{3}$, liberating metallic nickel that subsequently reacted to form NiO and/or $\mathrm{NiAl}_{2} \mathrm{O}_{4}$ spinel. The $\mathrm{Y}_{2} \mathrm{O}_{3}$ reacted with aluminum to ultimately form the YAG "mushrooms."

Thorium did not form any mixed oxides; the only oxide involving thorium was $\mathrm{ThO}_{2}$, which existed as small particles at the oxide-metal interface. A highly beneficial effect of the thoria particles in reducing film spalling was observed.

Scale spalling in the base alloy was attributed to void formation at the oxide-metal interface, the voids forming by condensation of excess vacancies from the Kirkendall effect associated with slow back-diffusion of nickel into the substrate as aluminum was preferentially oxidized and diffused rapidly outward. The mechanism of improved scale adherence in the quaternary alloys was the elimination of voids by annihilation of the Kirkendall vacancies at vacancy sinks introduced by the non-coherent interfaces between yttrium and thorium-containing intermetallics and/or oxides.

17. Key Words (Suggested by Author(s))

Kinetics, Diffusion, Oxide Scale, Defect

Structure, Internal Oxidation, Scale Adherence
18. Distribution Statement

UNCLASSIFIED-UNLIMITED

CAT. 17

\begin{tabular}{|c|c|c|c|}
\hline $\begin{array}{l}\text { 19. Security Classif \&of this report) } \\
\text { UNCLASSIFIED }\end{array}$ & $\begin{array}{c}\text { 20. Security Classif. (of this page) } \\
\text { UNCLASSIFIED }\end{array}$ & $\begin{array}{l}\text { 21. No. of Pages } \\
42\end{array}$ & $\begin{array}{r}\text { 22. Price* } \\
\$ 3.25\end{array}$ \\
\hline
\end{tabular}

*For sale by the National Technical Information Service, Springfield, Virginia 22151 
Page Intentionally Left Blank 
ABSTRACT

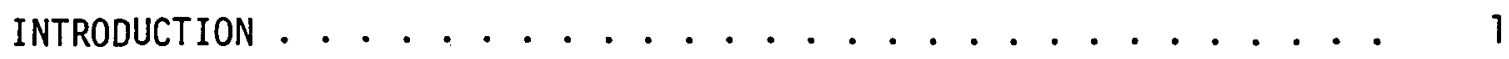

EXPERIMENTAL PROCEDURES ................... 2 Materials and Sample Preparation .................. 2 Oxidation Tests . ............................. 4 X-Ray Diffraction Studies. . . . . . . . . . . . . . . . 4 Scanning Electron Microscopy .................. 5 Metallographic Examination ............... 5

RESULTS ................................. 5

Oxidation Behavior of Ternary Ni-Cr-Al Alloys. . . . . . . 5

Effect of Quaternary Additions on Oxidation Behavior . . . . . 8

DISCUSSION . . . . . . . . . . . . . . 36

Oxidation of $\mathrm{Ni}-10 \mathrm{Cr}-5 \mathrm{Al} \ldots \ldots . \ldots 36$

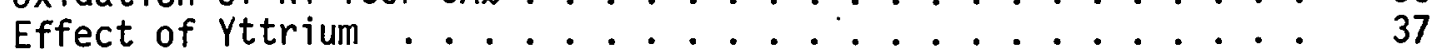

Effect of Thorium . . . . . . . . . . 38

Oxide Scale Adherence. . . . . . . . . . . . 39

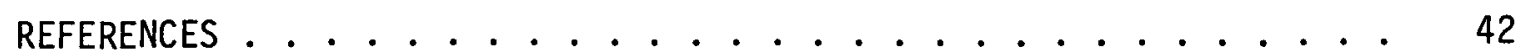




\section{ABSTRACT}

The effect of quaternary additions of $0.5 \% \mathrm{Y}, 0.5$ and $1.0 \%$ Th to a base alloy of $\mathrm{Ni}-10 \mathrm{Cr}-5 \mathrm{Al}$ on the oxidation behavior and mechanism was studied during oxidation in air over the range of 1000 to $1200^{\circ} \mathrm{C}$. The presence of yttrium decreased the oxidation kinetics slightly, whereas, the addition of thorium caused a slight increase. 0xide scale adherence was markedly improved by the addition of the quaternary elements.

Although a number of oxides formed on yttrium-containing alloys, quantitative $X$-ray diffraction clearly showed that the rate-controlling step was the diffusion of aluminum through short-circuit paths in a thin layer of alumina that formed parabolically with time. Mixed oxides containing both aluminum and yttrium formed by the reaction of $\mathrm{Y}_{2} \mathrm{O}_{3}$ to form $\mathrm{YAlO}_{3}$ initially, and $\mathrm{Y}_{3} \mathrm{Al}_{5} \mathrm{O}_{12}$ (YAG) after longer times. Although the scale adherence of the yttrium-containing alloy was considerably better than the base alloys, spalling did occur that was attributed to the formation of the voluminous YAG particles which grew in a "mushroom"-like manner, lifting the protective scale off the substrate locally. The YAG particles formed primarily at grain boundaries in the substrate in which the yttrium originally existed as $\mathrm{YNi}_{9}$. This intermetallic compound reacted to form $\mathrm{Y}_{2} \mathrm{O}_{3}$, liberating metallic nickel that subsequently reacted to form $\mathrm{NiO}$ and/or $\mathrm{NiAl}_{2} \mathrm{O}_{4}$ spinel. The $\mathrm{Y}_{2} \mathrm{O}_{3}$ reacted with aluminum to ultimately form the YAG "mushrooms."

Thorium did not form any mixed oxides; the only oxide involving thorium was $\mathrm{ThO}_{2}$, which existed as small particles at the oxide-metal interface. A highly beneficial effect of the thoria particles in reducing film spalling was observed.

Scale spalling in the base alloy was attributed to void formation at the oxide-metal interface, the voids forming by condensation of excess vacancies from the Kirkendall effect associated with slow back-diffusion of nickel into the substrate as aluminum was preferentially oxidized and diffused rapidly outward. The mechanism of improved scale adherence in the quaternary alloys was the elimination of voids by annihilation of the Kirkendall vacancies at vacancy sinks introduced by the non-coherent interfaces between yttrium and thorium-containing intermetallics and/or oxides. 


\section{INTRODUCTION}

Low strength and poor oxidation resistance limit the use of nickelbase alloys for high temperature structural applications in the range of 1000 to $1200^{\circ} \mathrm{C}$. The strength of these alloys decreases markedly with increasing temperature. The lack of strength has been overcome by dispersion hardening the materials with thoria particles, producing thoriadispersed-nickel (TD-Ni) and thoria-dispersed nichrome (TD-Ni-2OCr). However, the oxidation resistance of these materials has still not proven adequate for their use as structural components at high temperatures. It was of interest, therefore, to improve the oxidation resistance of $\mathrm{Ni}-\mathrm{Cr}$ alloys with ternary and quaternary additions, so that more oxidation resistant matrices can be obtained, to which dispersoids can be added for high-temperature strength.

The initial oxidation of "Nichrome"-type alloys ( $\mathrm{Ni}-2 \mathrm{OCr}$ ) occurs with the formation of a NiO layer by outward nickel cation diffusion, enriching the substrate with chromium. Eventualiy, the chromium reacts with NiO and/or dissolved oxygen to form $\mathrm{Cr}_{2} \mathrm{O}_{3}$ beneath the $\mathrm{NiO}$ layer. The composite layer of $\mathrm{NiO}$ and $\mathrm{Cr}_{2} \mathrm{O}_{3}$ is thermodynamically unstable at high temperatures and reacts to form the spinel $\mathrm{NiCr}_{2} \mathrm{O}_{4}$. Thus, after a sufficiently long time, the scale will consist of an outer layer of spinel and an inner layer of $\mathrm{Cr}_{2} \mathrm{O}_{3} .(1,2)$ If the chromium content is increased above $25 \%$, only $\mathrm{Cr}_{2} \mathrm{O}_{3}$ forms as the outer layer. When $\mathrm{Cr}_{2} \mathrm{O}_{3}$ is the outer layer, it oxidizes to $\mathrm{CrO}_{3}$ at very high temperatures (above $1000^{\circ} \mathrm{C}$ ). $\mathrm{CrO}_{3}$ is a gas and offers no protection. Thus, in order to achieve high-temperature oxidation resistance, it is necessary to form an oxide scale which is not volatile and which has a low defect concentration.

An example of an oxide that fulfills these requirements is $\mathrm{Al}_{2} \mathrm{O}_{3}$, which forms during the oxidation of binary alloys containing aluminum, if the aluminum content is high enough. The addition of aluminum to nickel should, in principle, result in alloys that could be oxidized to form $\mathrm{Al}_{2} \mathrm{O}_{3}$ scales, the oxidation behavior being analogous to that of $\mathrm{Ni}-\mathrm{Cr}$ alloys. However, the $\mathrm{Al}_{2} \mathrm{O}_{3}$ film of $\mathrm{Ni}$-Al alloys spalls readily, ${ }^{(3)}$ but if some critical amount of chromium exists in the alloy, the spalling tendency is reduced. 
The amount of aluminum required to form $\mathrm{Al}_{2} \mathrm{O}_{3}$ depends on the chromium content of the alloys as shown in Fig. 1, which is an "oxide-map" of the $\mathrm{Ni}-\mathrm{Cr}$-Al system ${ }^{(4)}$ at $1000^{\circ} \mathrm{C}$. It has been shown that $\mathrm{Ni}-\mathrm{Cr}$-Al alloys generally exhibit excellent oxidation resistance. $(5,6)$ Kvernes and Kofstad $(5)$ found that the best alloy composition was $\mathrm{Ni}-9.3 \mathrm{Cr}-5.8 \mathrm{Al}$ for optimum isothermal oxidation resistance.

It has been found also that small additions of reactive metals, e.g., $Y$, Th, Ca, Ce, Sm, etc. are very beneficial and provide good oxidation resistance and/or scale adherence. Kvernes and Kofstad ${ }^{(5)}$ added up to $0.7 \mathrm{w} / \mathrm{O}$ yttrium to a $\mathrm{Ni}-9 \mathrm{Cr}-6 \mathrm{Al}$ alloy and found improved scale adherence and a reduction in the oxidation rate. Yttrium existed in the grain boundaries of the alloy in the form of $\mathrm{Ni}-\mathrm{Y}$ intermetallics which oxidized preferentially, giving rise to a "keying-on" effect of the oxide scale. There was no yttrium found in the scales. This observation is not in agreement with that of Kuenzly and Douglass, who observed an enrichment only at the inner portion of the oxide formed at $1200^{\circ} \mathrm{C}$ on a $\mathrm{Ni}-20 \mathrm{Cr}-1 \mathrm{Y}$ alloy.

This study involved the determination of the optimum composition of a $\mathrm{Ni}-\mathrm{Cr}$-Al ternary alloy for both oxidation resistance and the least tendency for spalling of the films. Small amounts of yttrium and thorium were added to this $\mathrm{Ni}-\mathrm{Cr}$-Al ternary alloy, and the mechanism of oxidation and the oxide scale adherence was determined.

\section{EXPERIMENTAL PROCEDURES}

Materials and Sample Preparation

The following metals were used for melting of alloys: Ni--99.99\%, Cr--99.99\%, Al--99.999\%, Y--99.9\%, and Th--99.5\%. The charges were pickled in order to remove any surface films that might exist, rinsed, and ultrasonically cleaned in acetone. The weighed charges (total of about 100 grams) were arc-melted in argon with a non-consumable electrode. The argon was gettered with a titanium button that was melted, thereby removing any residual oxygen or nitrogen. The buttons were turned over and remelted five times in order to obtain homogeneity. Melting losses 


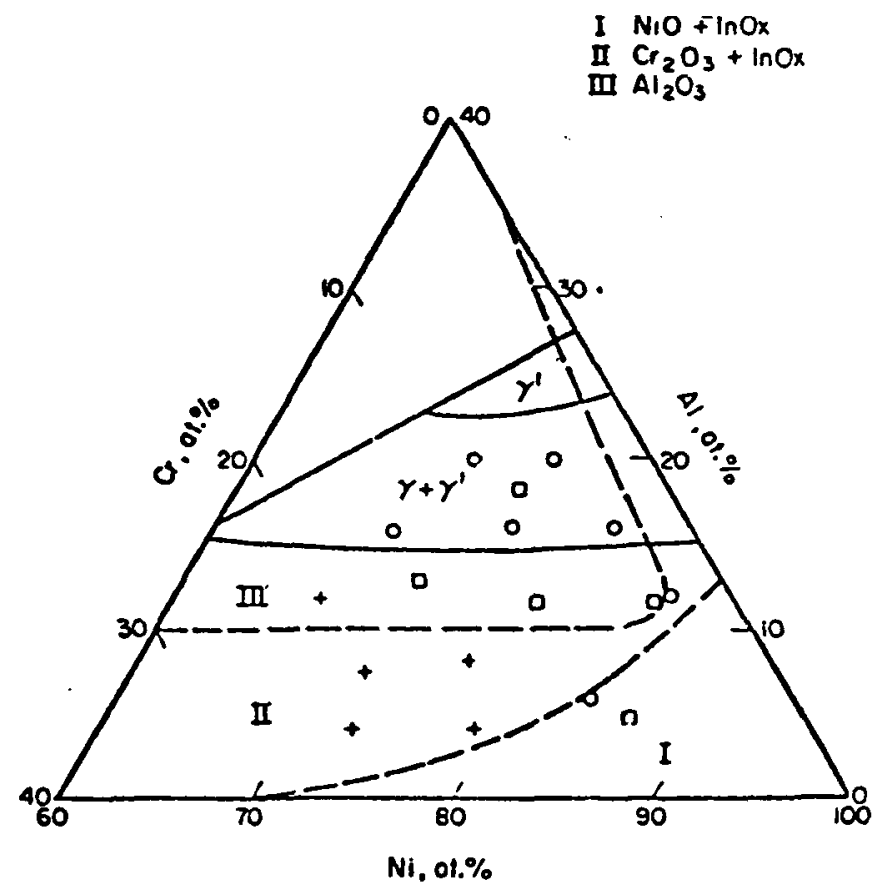

Fig. 1 Oxide map for the ternary system $\mathrm{Ni}-\mathrm{Cr}-\mathrm{Al}$ at $1000^{\circ} \mathrm{C} .{ }^{(4)}$ 
were about $0.1 \%$ or less, and thus the compositions were taken as the nominal ones.

The buttons were cut into slices about 0.1 inch thick with a metallographic cutoff wheel. The slices were cleaned with acetone and given

a homogenization treatment for $24 \mathrm{hrs}$. at $1000^{\circ} \mathrm{C}$ in vacuum $\left(10^{-6}\right.$ torr). The slices were ground through 4/0 emery paper and vacuum-annealed for 30 mins. at $900^{\circ} \mathrm{C}$.

\section{Oxidation Tests}

Thermal gravimetric analyses were performed in a Harrop Unit that required about 20 mins. to reach a temperature of $1200^{\circ} \mathrm{C}$. The weight gain increased rapidly with time during heat up, commencing at a temperature of about $900^{\circ} \mathrm{C}$. This problem was eliminated by preoxidizing the sample in another furnace by rapidly immersing the samples into the furnace which was already at the desired temperature. This method would produce those oxides which were characteristic of the actual oxidizing temperature rather than those formed upon heating. All the samples with yttrium and thorium additions were initially weighed and preoxidized at the temperature of oxidation for one-half hour. No spalling was observed during cooling to room temperature. These samples were subsequently reweighed and introduced in a Harrop thermal gravimetric unit which was then heated to the temperature of oxidation. No changes were observed during heating when the samples were preoxidized. Samples of the base

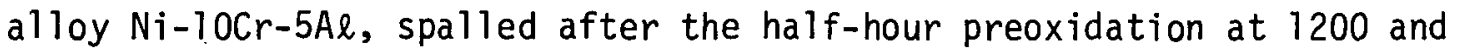
$1150^{\circ} \mathrm{C}$, hence the Harrop unit was modified for direct immersion of the sample into the hot-zone of the furnace at the oxidation temperature.

The quarternary alloys containing $Y$ and Th exhibited no spalling either at temperature during the test or during the cool-down after oxidation.

Various pretreatments were studied which were shown to have an effect on the oxidation kinetics. On the basis of these tests a standard pretreatment of vacuum-annealing for 30 mins. at $900^{\circ} \mathrm{C}$ was adopted.

X-Ray Diffraction Studies

The oxides formed during oxidation were identified by X-ray diffraction studies made on the "in-situ" scales and spalled oxides. A Phillips 
Norelco diffractometer was used with nickel-filtered copper radiation.

The transient stage of oxidation was studied by immersing the alloy samples directly into the hot-zone of the furnace for varying times. The development of various oxidation products and the sequence of their formation were studied by $X$-ray diffraction.

Scanning Electron Microscopy

The scanning electron microscope (SEM) was used to study the surface features of the oxides, and the mode of fracture of the spalled oxides. Identification of the phases present was performed with an X-ray image and microprobe attachment to the SEM using line-scans for various elements. Metallographic Examination

The oxidized samples were vapor-deposited with silver, and then a heavy coating of copper was applied electrolytically. A thin vapor coating of silver was necessary for copper plating. The copper coating was applied in order to keep the oxide film from fracturing during the metallographic preparation. A Bausch and Lomb metallograph was used to examine the samples.

\section{$\underline{\text { RESULTS }}$}

\section{Oxidation Behavior of Ternary $\mathrm{Ni}-\mathrm{Cr}$-Al Alloys}

The first tests were conducted on ternary $\mathrm{Ni}-\mathrm{Cr}-\mathrm{Al}$ alloys in order to determine the best alloy to which quaternary additions could be made. Selection of compositions was based on data in the literature $(4,5,8,9)$ regarding oxidation rates, film spalling, and fabricability. Three compositions were initially selected, shown in Fig. 2, and tested. The results of these tests were used to select additional compositions, also shown in Fig. 2 along with Kvernes and Kofstad's alloys.

The kinetics of oxidation are shown in Fig. 3 as a $\log -\log$ plot of weight gain vs. time. The log-log plots were used for convenience in covering several decades of time. The alloys showed two distinct classifications: Group 1 ( $\mathrm{Ni}-12 \mathrm{Cr}-3 \mathrm{Al}$ and $\mathrm{Ni}-5 \mathrm{Cr}-5 \mathrm{Al}$ ) oxidized much more rapid1y than Group 2. The $\mathrm{Ni}-5 \mathrm{Cr}-5 \mathrm{Al}$ alloy exhibited variable behavior, some samples exhibiting Group-2 behavior.

All of the ternary alloys except one, Ni-12Cr-3Al, exhibited extensive spalling of their oxides during cooling from the oxidation temperature. 


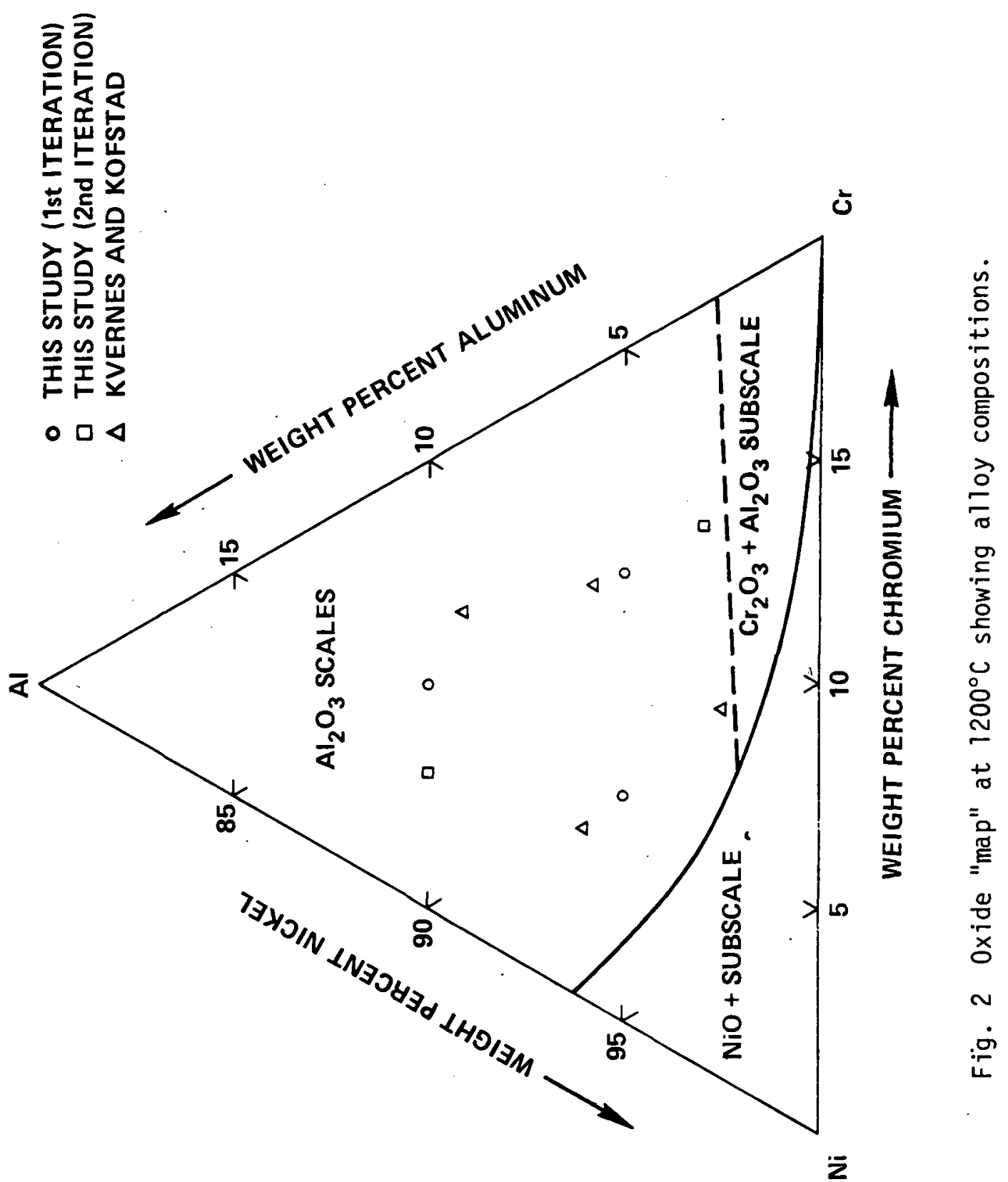




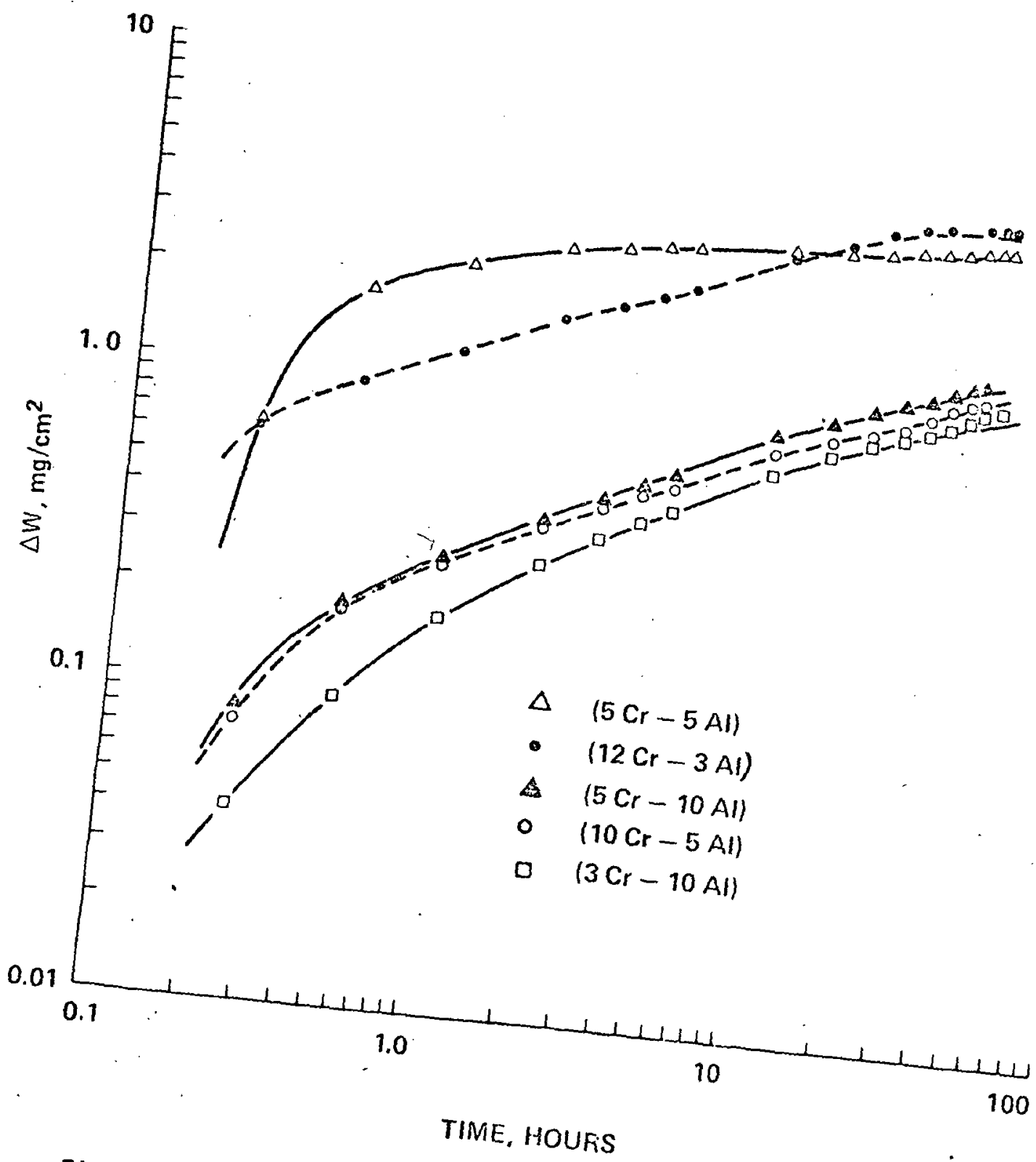

Fig. 3 Oxidation kinetics of $\mathrm{Ni}-\mathrm{Cr}-\mathrm{Al}$ alloys in Air at $1200^{\circ} \mathrm{C}$. 
Effect of Quaternary Additions on Oxidation Behavior

Two of the ternary alloys were selected as base compositions to which $0.5 \% \mathrm{Y}$ was added. The first, $\mathrm{Ni}-10 \mathrm{Cr}-5 \mathrm{Al}$, was near optimum with respect to oxidation behavior, and the second, $\mathrm{Ni}-12 \mathrm{Cr}-3 \mathrm{Al}$, was the only alloy that could be cold-rolled. This alloy exhibited less than optimum oxidation resistance, but it was thought that yttrium might markedly improve the oxidation and yet not impair the fabricability. As will be shown, the oxidation behavior was improved with the yttrium addition, but the fabricability was decreased. Thorium was added to the Ni-10Cr-5Al alloy. Both yttrium and thorium improve the scale adherence of these alloys. Three alloys, Ni-10Cr-5Al-0.5Y, Ni-10Cr-5Al-0.5Th and Ni-10Cr-5Al-1Th were oxidized at $1000,1100,1150$ and $1200^{\circ} \mathrm{C}$ and intensively studied.

The effect of yttrium on the oxidation kinetics is shown in Fig. 4. Little difference, probably within experimental scatter, was noted for the $\mathrm{Ni}-10 \mathrm{Cr}-5 \mathrm{Al}$ alloy with and without yttrium, but a noticeable decrease in oxidation rate occurred upon the addition of $0.5 \% \mathrm{Y}$ to $\mathrm{Ni}-12 \mathrm{Cr}-3 \mathrm{Al}$.

The effect of temperature on the oxidation behavior of $\mathrm{Ni}-10 \mathrm{Cr}-5 \mathrm{Al}$, $\mathrm{Ni}-10 \mathrm{Cr}-5 \mathrm{Al}-0.5 \mathrm{Y}, \mathrm{Ni}-10 \mathrm{Cr}-5 \mathrm{Al}-0.5 \mathrm{Th}$, and $\mathrm{Ni}-10 \mathrm{Cr}-5 \mathrm{Al}-1 \mathrm{Th}$ is shown in Figs. 5-8, and the corresponding parabolic plots are shown in Figs. 9-12, respectively. The base alloy $\mathrm{Ni}-10 \mathrm{Cr}-5 \mathrm{Al}$ had a variable oxidation behavior at $1000^{\circ} \mathrm{C}$, and so the results are not reported. For the alloys with $Y$ and Th additions, however, reproducible results were obtained from 1000 to $1200^{\circ} \mathrm{C}$. All the thermogravimetric data were obtained on at least two samples.

None of the alloys followed a strict parabolic time dependence as noted by the continuously decreasing slope of parabolic plots. The parabolic plots indicate that the overall reaction is diffusion-controlled after extended oxidation. However, because more than one oxide forms, no physical interpretation should be associated with the apparent long-time parabolic behavior; the parabolic rate constants were determined for comparative purposes, as shown in Fig. 13, an Arrhenius plot of the rate constants. This plot also includes data for pure nickel and a $\mathrm{Ni}-25 \mathrm{~W} / \mathrm{OAl}$ which forms 


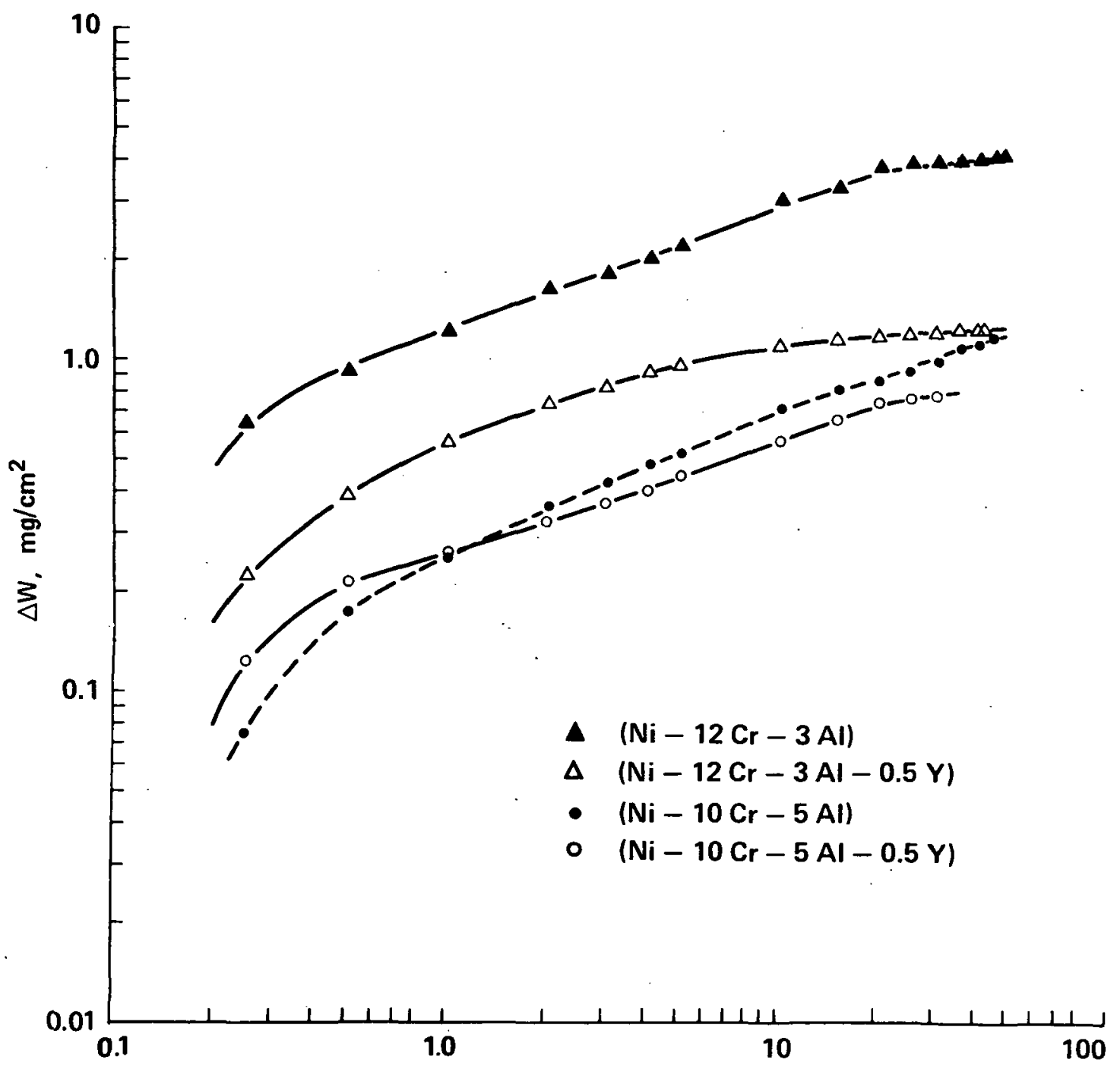

TIME, HOURS

Fig. 4 Effect of yttrium on the oxidation kinetics of two Ni-Cr-Al alloys at $1200^{\circ} \mathrm{C}$ in air. 


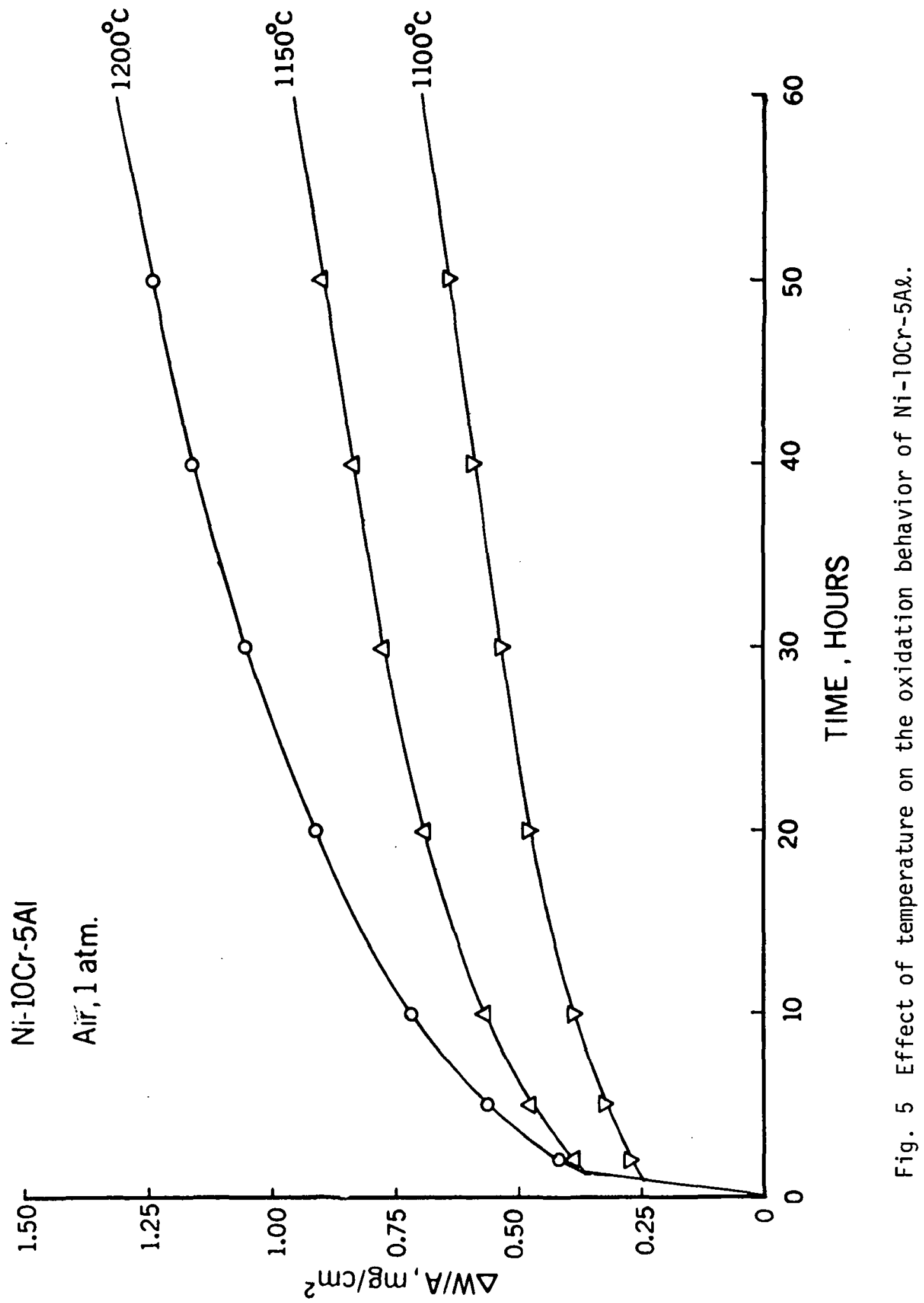




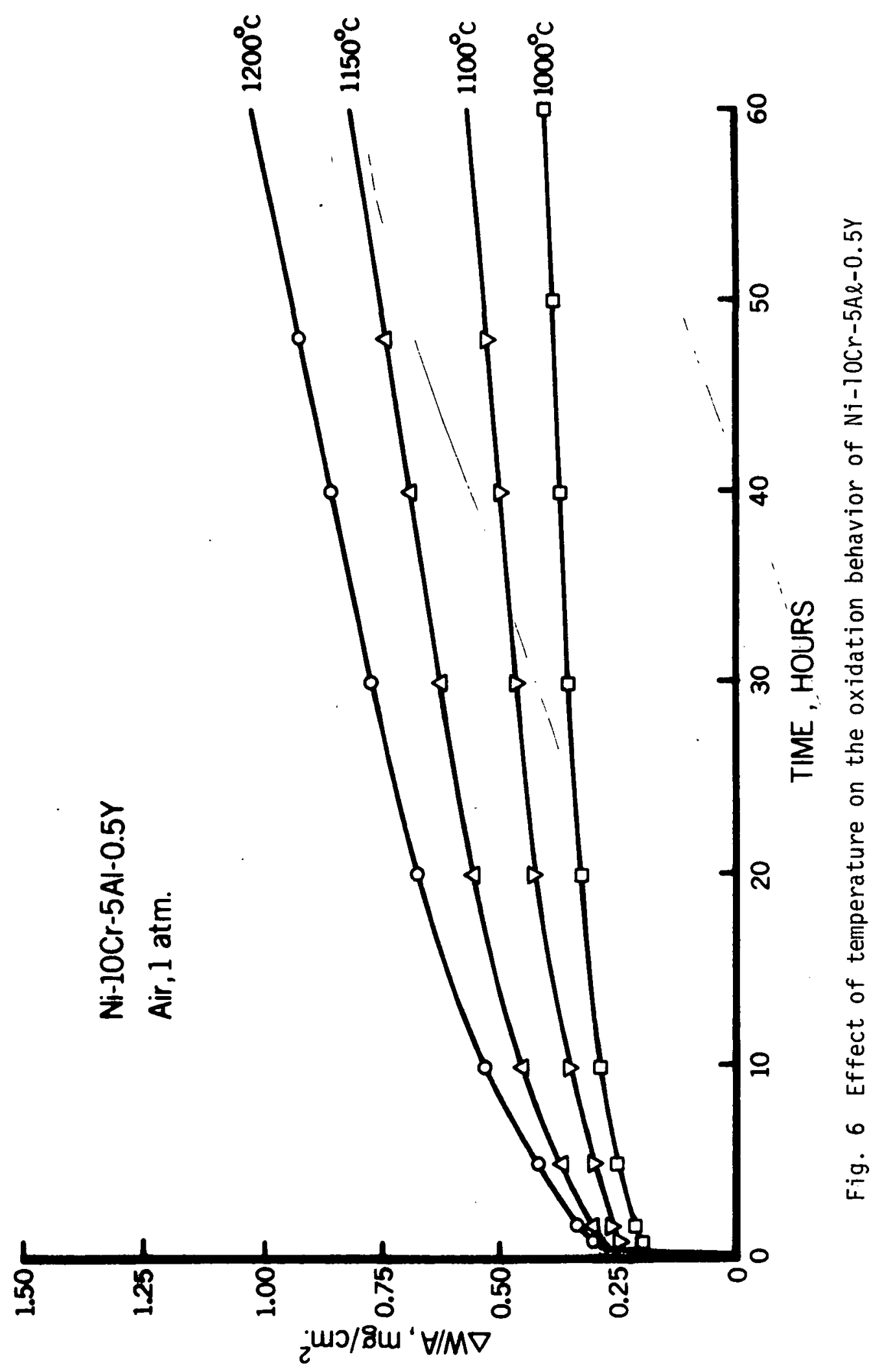


12

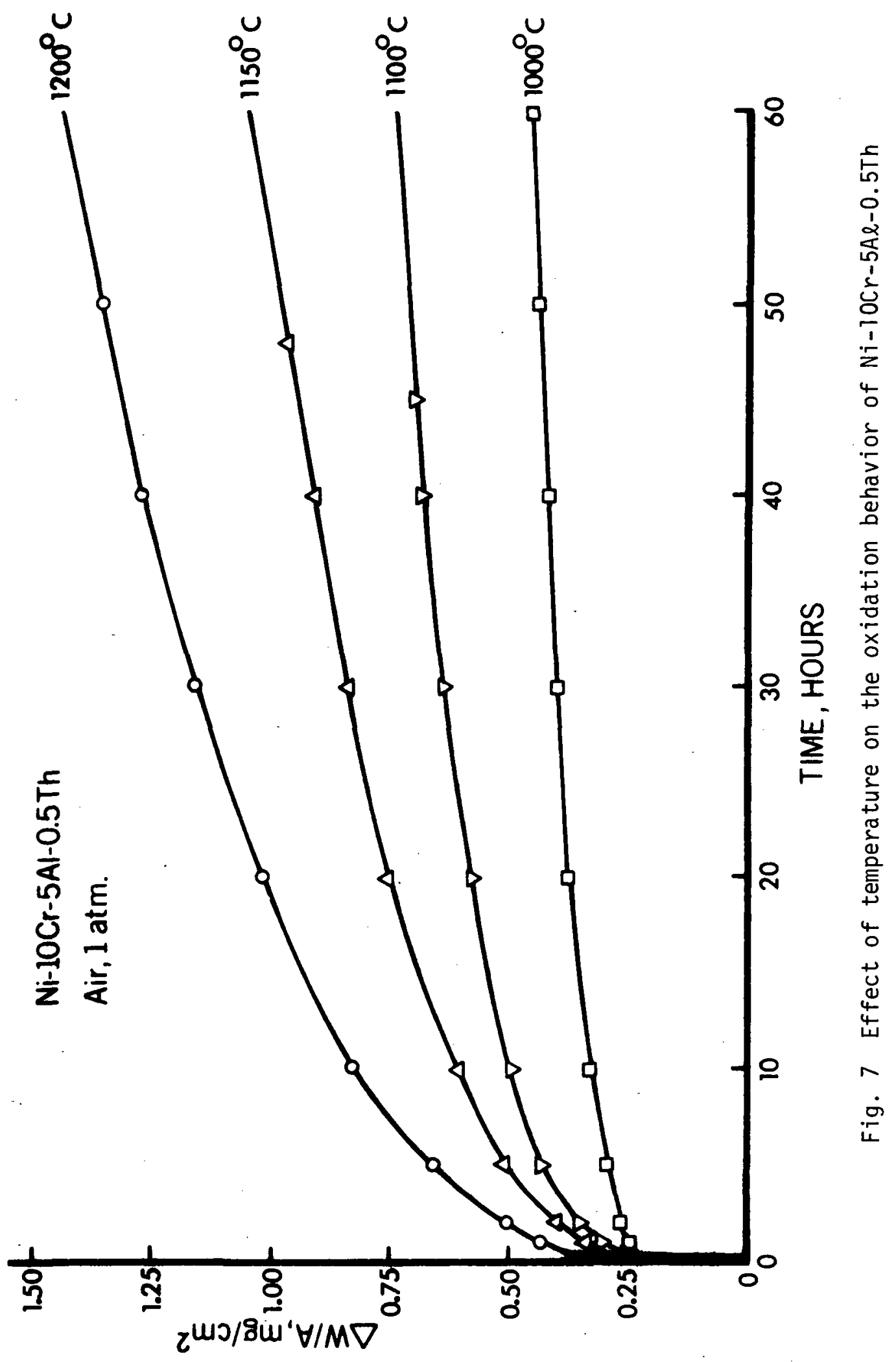




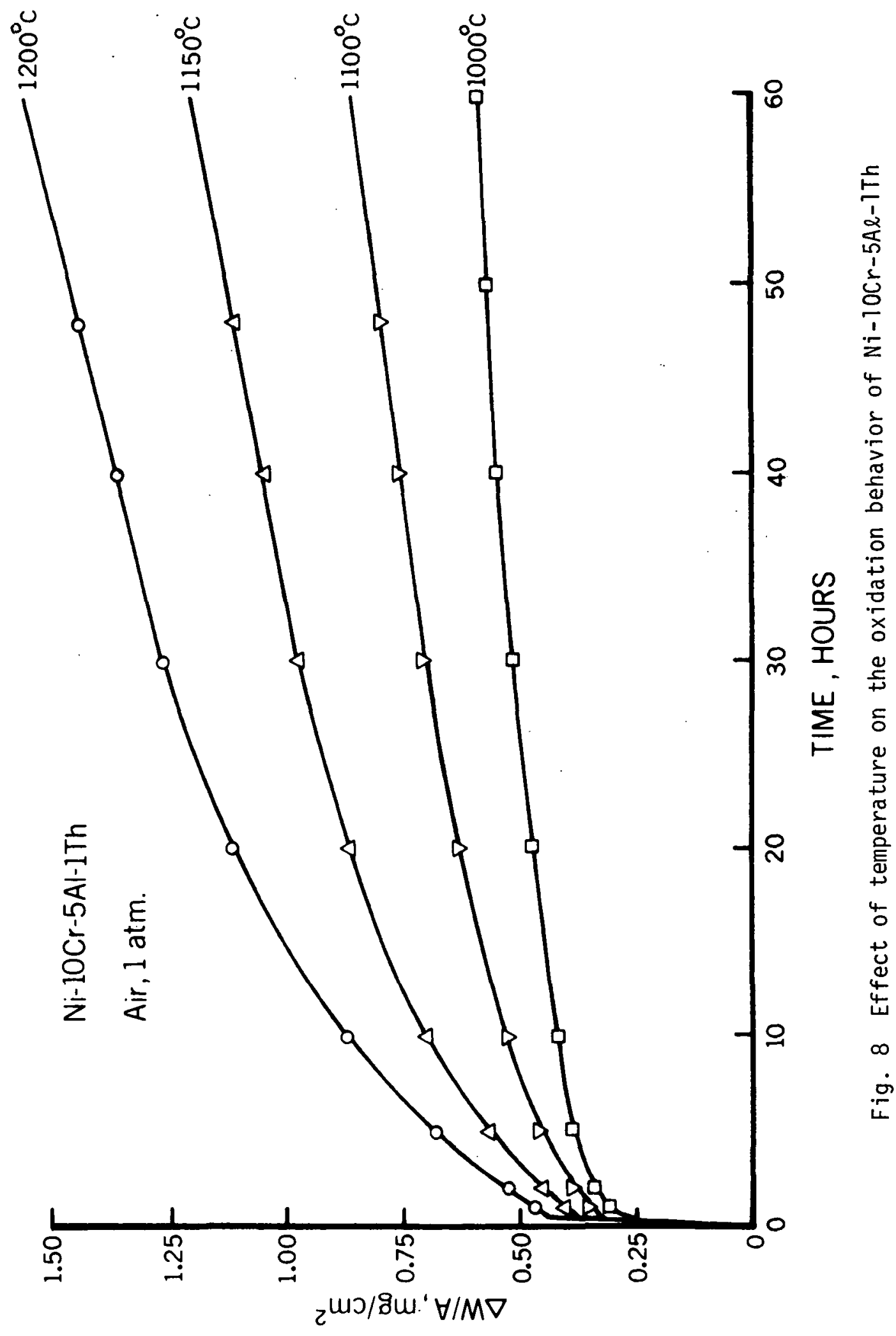




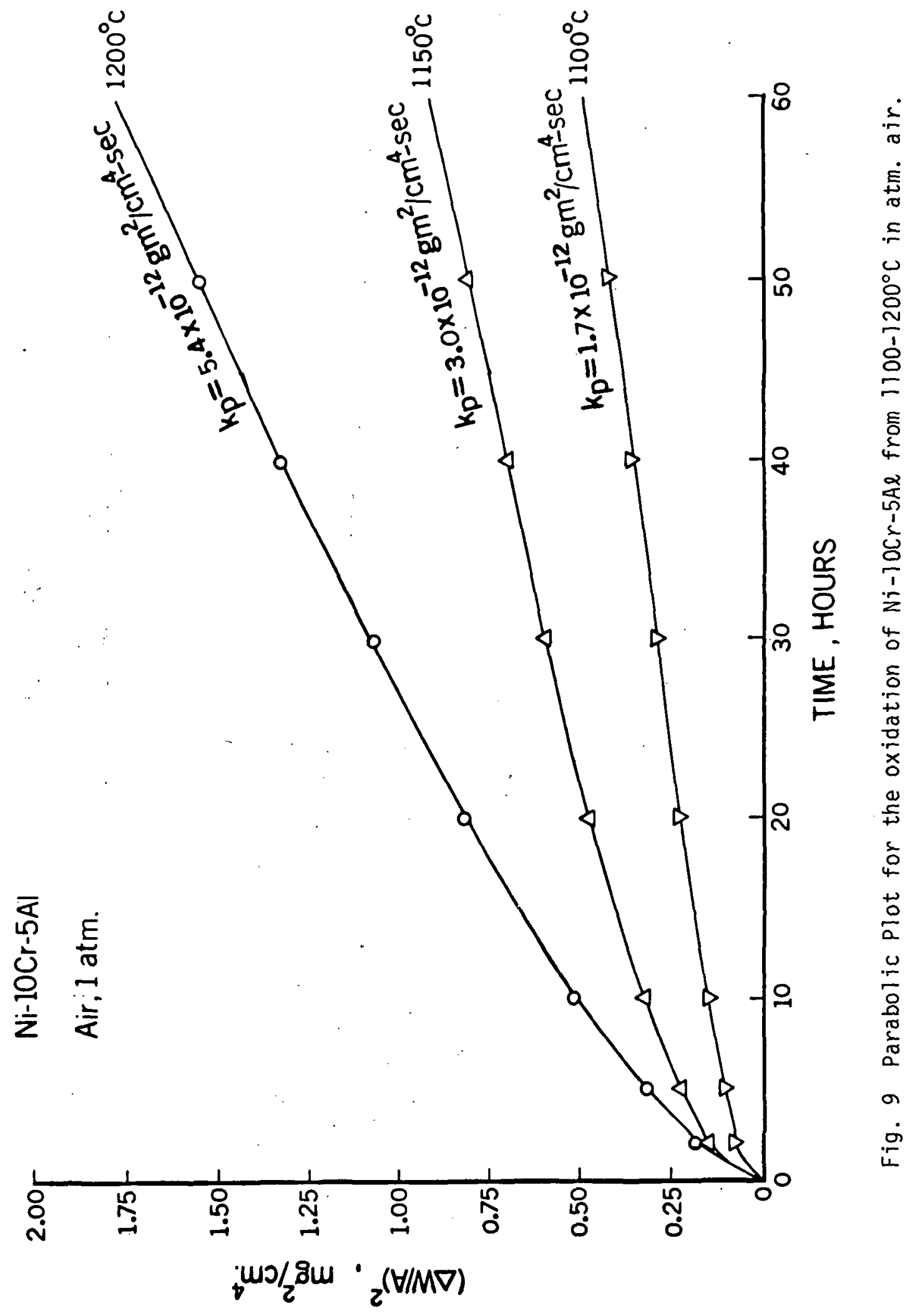


$\stackrel{0}{\circ}$

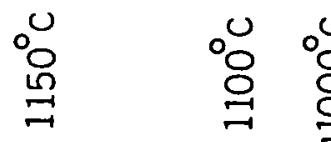

$\frac{\dot{\varepsilon}}{\pi}$

1 ol 1 ग

है

更

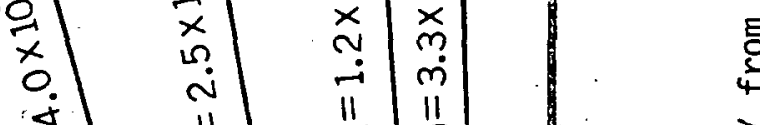
11

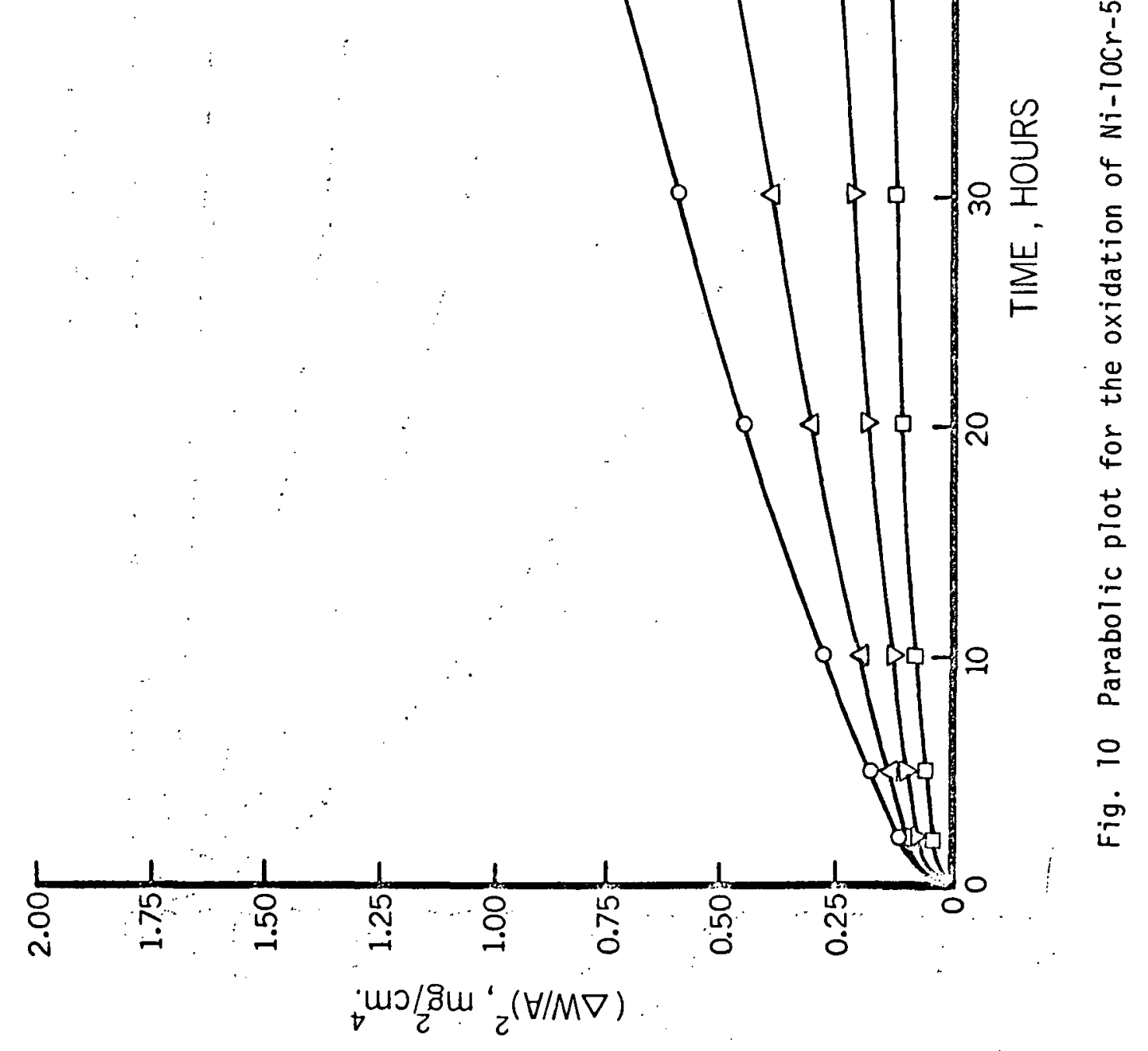




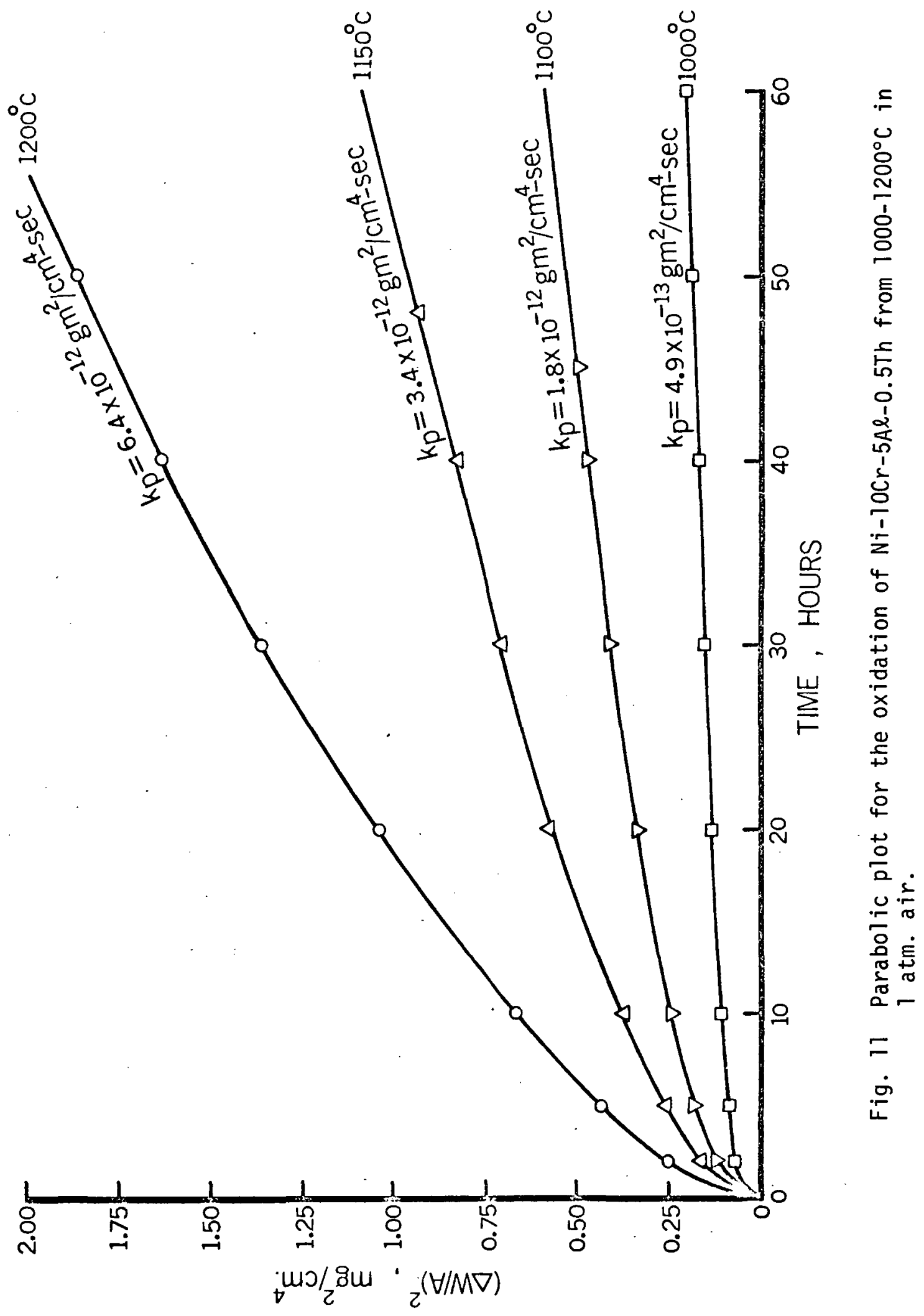




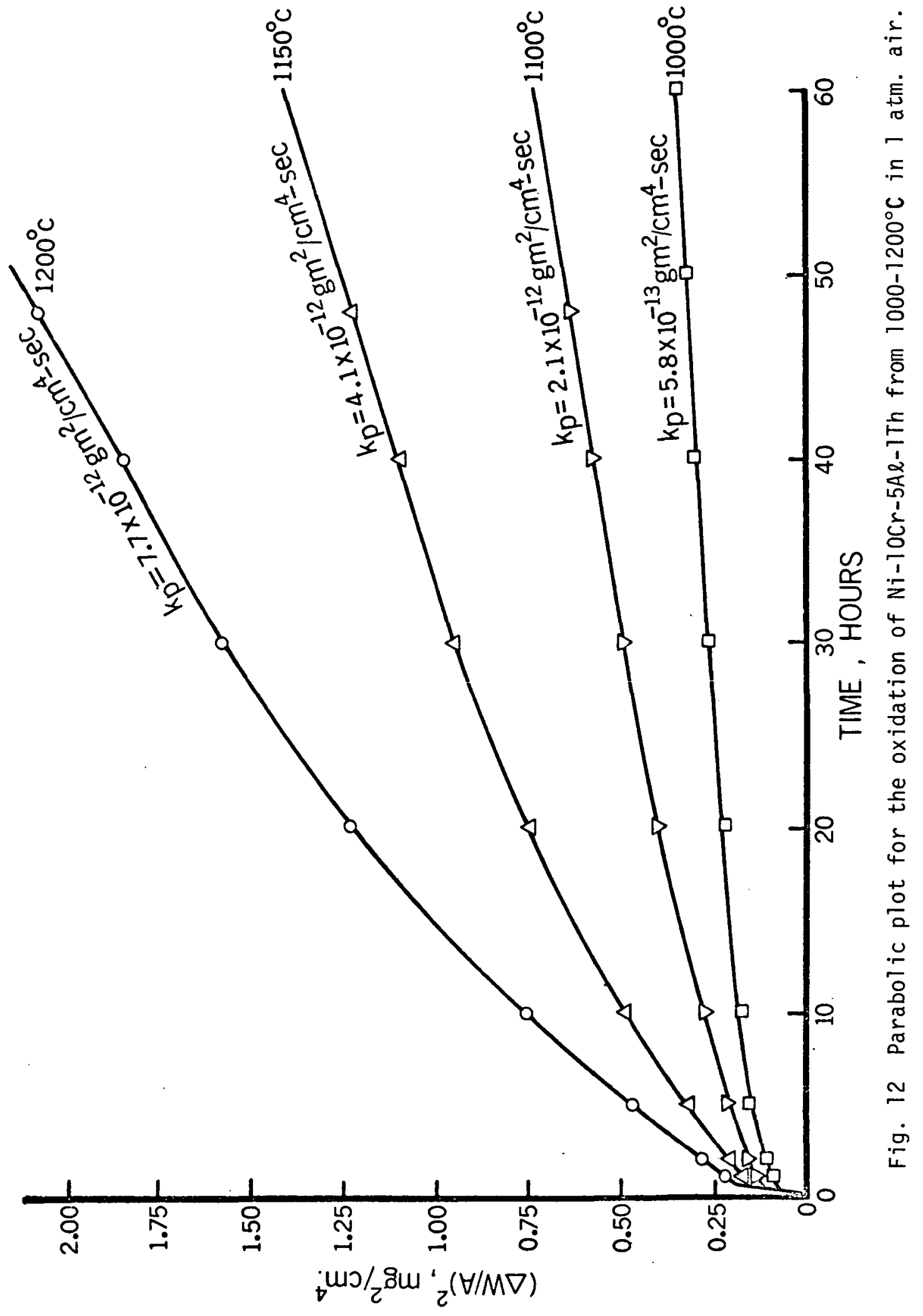




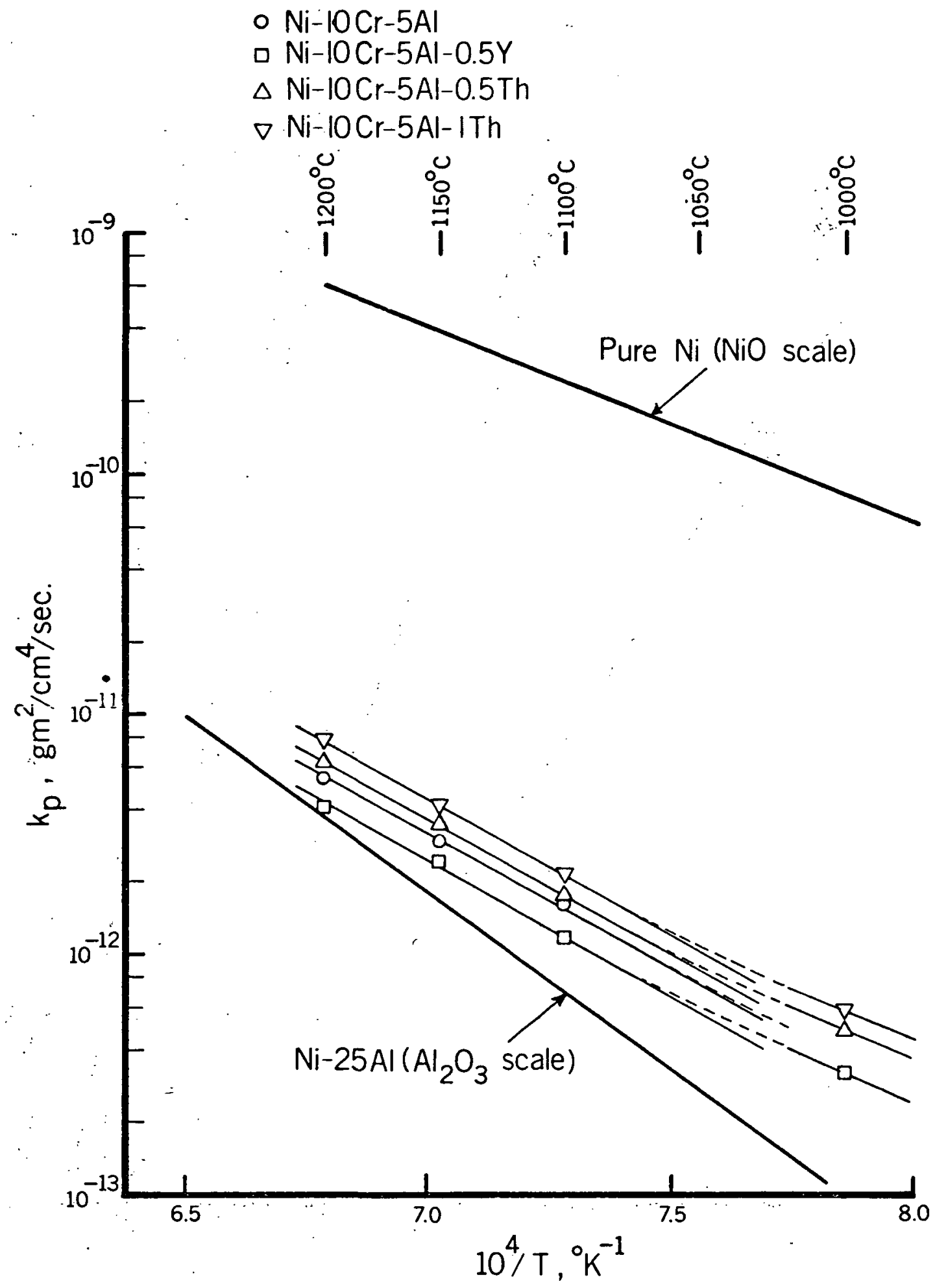

Fig. 13 Arrhenius plot for various alloys showing temperature dependence. 
$\alpha-\mathrm{Al}_{2} \mathrm{O}_{3}$ upon oxidation. It can be seen that at $1000^{\circ} \mathrm{C}$, the data points deviate from a straight line. This is due to the formation of Ni0, the main oxide on these alloys at lower temperatures. The activation energies for all alloys were almost the same, e.g., approximately $50 \mathrm{Kcal} / \mathrm{mole}$. It is also evident that thorium increases the oxidation rate of $\mathrm{Ni}-10 \mathrm{Cr}-5 \mathrm{Al}$ slightly, whereas, yttrium caused a slight decrease in the oxidation rate.

$X$-ray diffraction analyses were made on "in-situ" oxide scales, and whenever possible, on the spalled oxides. A summary of the oxide phases present and their relative amounts is given in Table I for various alloys oxidized in static air at $1 \mathrm{~atm}$. at the temperature and time indicated. It is evident that for the $\mathrm{Ni}-10 \mathrm{Cr}-5 \mathrm{Al}$ alloy with yttrium or thorium additions, the amount of $\alpha-\mathrm{Al}_{2} \mathrm{O}_{3}$ and $\mathrm{NiAl}_{2} \mathrm{O}_{4}$ increases while the amount of $\mathrm{NiO}$ decreases with an increase in the oxidation temperature. In addition to $\alpha-\mathrm{Al}_{2} \mathrm{O}_{3}, \mathrm{NiAl}_{2} \mathrm{O}_{4}$ and $\mathrm{NiO}$, the $\mathrm{Ni}-10 \mathrm{Cr}-5 \mathrm{Al}-0.5 \mathrm{Y}$ alloy al so shows a weak peak of $\mathrm{Y}_{2} \mathrm{O}_{3}$ at $1000^{\circ} \mathrm{C}, \mathrm{YAlO}_{3}$ from 1100 to $1200^{\circ} \mathrm{C}$, and $\mathrm{Y}_{3} \mathrm{Al}_{5} \mathrm{O}_{12}$ at 1150 and $1200^{\circ} \mathrm{C}$. The $\mathrm{Ni}-10 \mathrm{Cr}-5 \mathrm{Al}-0.5 \mathrm{Th}$ and $\mathrm{Ni}-10 \mathrm{Cr}-5 \mathrm{Al}-1 \mathrm{Th}$ alloys exhibited a weak peak for $\mathrm{ThO}_{2}$; no complex oxides containing thorium were detected.

The development of oxides on $\mathrm{Ni}-10 \mathrm{Cr}-5 \mathrm{Al}-0.5 \mathrm{Y}$ at $1200^{\circ} \mathrm{C}$ was studied as a function of time using quantitative $X$-ray diffractometry. Fig. 14 shows the transient stages of oxide scale development for periods ranging from 5 to 400 mins. It can be seen that NiO nucleates and grows very rapidly while $\alpha-\mathrm{Al}_{2} \mathrm{O}_{3}$ and $\mathrm{NiAl}_{2} \mathrm{O}_{4}$ form discrete nuclei within the first few minutes. Very small amounts of $\mathrm{Cr}_{2} \mathrm{O}_{3}$ and $\mathrm{NiCr}_{2} \mathrm{O}_{4}$ were also detected after 5 mins. At the same time, $\mathrm{Ni}-\mathrm{Y}$ intermetallics are converted to $\mathrm{Y}_{2} \mathrm{O}_{3}$, which subsequently disappears after about 100 mins., combining with $\alpha-\mathrm{Al}_{2} \mathrm{O}_{3}$ to form the double oxide, $\mathrm{YAlO}_{3}$. With increasing time, $\alpha-\mathrm{Al}_{2} \mathrm{O}_{3}$ grows and more $\alpha-\mathrm{Al}_{2} \mathrm{O}_{3}$ reacts with $\mathrm{YAlO}_{3}$ to form $\mathrm{Y}_{3} \mathrm{Al}_{5} \mathrm{O}_{12}$ (garnet structure). A diffuse peak for the $Y$-Al garnet (YAG) appears after approximately 200 mins. The appearance of the YAG corresponds to the onset of iimited spalling of the outer oxide layer, which can be seen also by the increase in the intensity of the substrate reflection. An analysis of the diffracted intensities from various oxides revealed that the thickness of the $\alpha-\mathrm{Al}_{2} \mathrm{O}_{3}$ layer increases parabolically with time. 


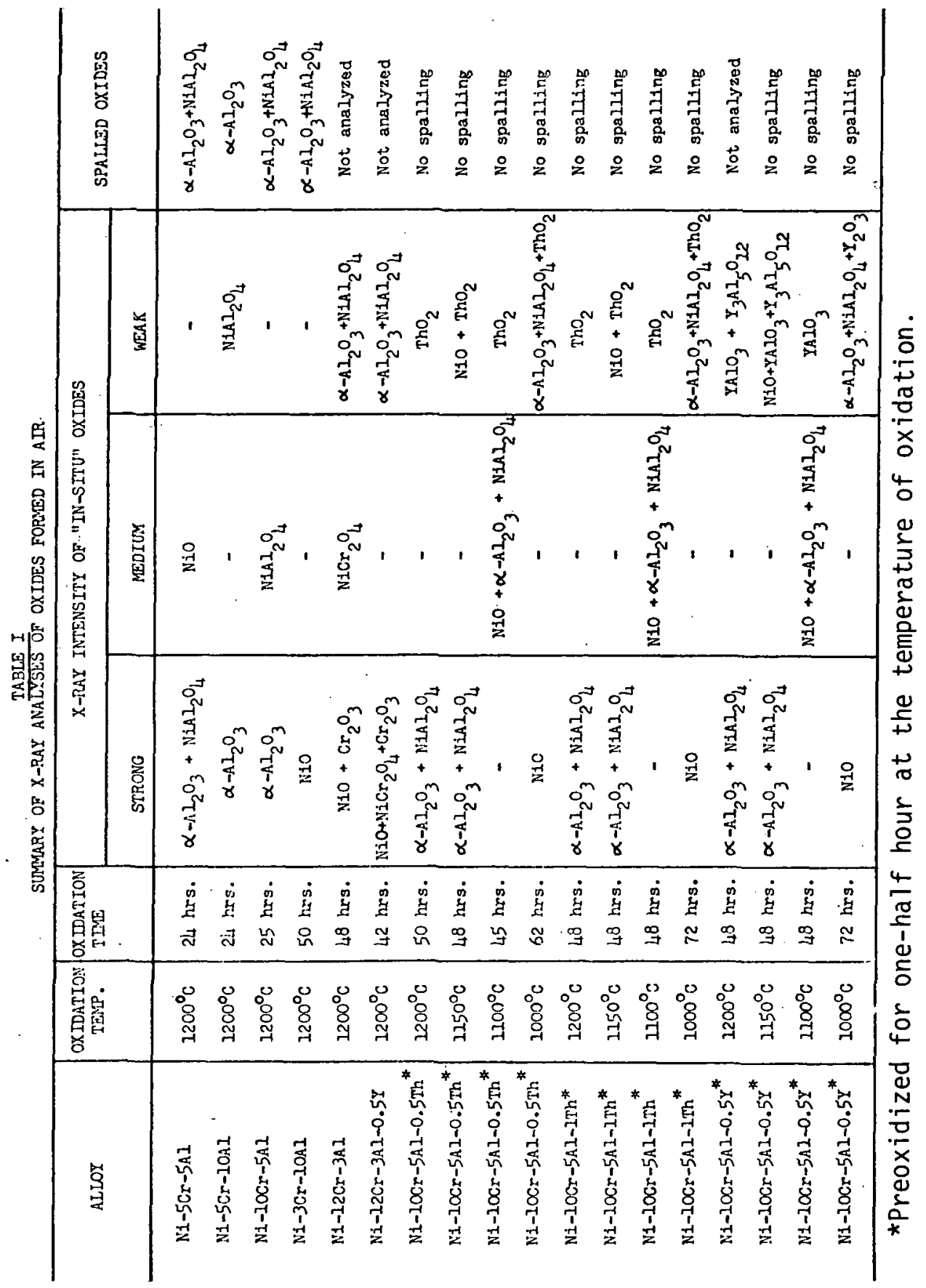




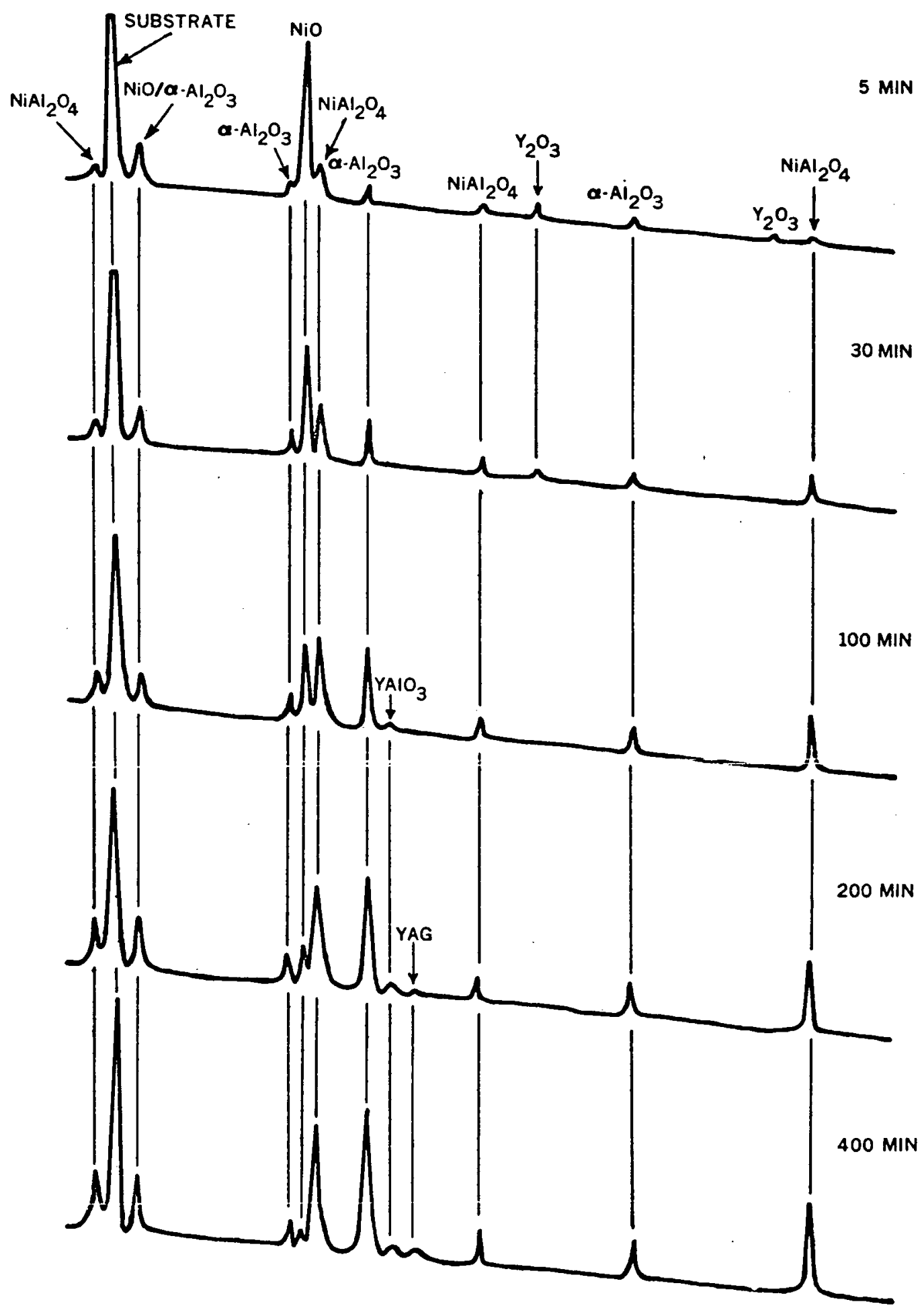

Fig. $14 X$-ray diffractometer traces of the oxide scale development on $\mathrm{Ni}-10 \mathrm{Cr}-5 \mathrm{Al}-0.5 \mathrm{Y}$ at $1200^{\circ} \mathrm{C}$. 
Fig. 15 is a plot of $\log$ peak intensity vs. log time for various oxides. The intensities were obtained from the diffractometer traces by slow scanning at $1 / 8^{\circ}$ per min. Since the integral breadth indicated very little or no strain and/or particle-size broadening, peak intensities were used instead of integrated intensities. NiO decreases with increasing oxidation time, whereas $\mathrm{NiAl}_{2} \mathrm{O}_{4}$ increases initially and decrease subsequently at extended times. This is because $\mathrm{NiO}$ reacts with $\alpha-\mathrm{Al}_{2} \mathrm{O}_{3}$ to form $\mathrm{NiAl}_{2} \mathrm{O}_{4}$ via a solid-state reaction; thus, when a continuous layer of $\alpha-\mathrm{Al}_{2} \mathrm{O}_{3}$ is formed beneath $\mathrm{NiO}$, the only $\mathrm{NiO}$ available for this reaction is that which formed during the initial stages of oxidation, e.g., on the outside. The amount of $\mathrm{NiAl}_{2} \mathrm{O}_{4}$ increases while the reaction is taking place but then decreases as the NiO is being used up and no more NiO is available for the reaction. Some $\mathrm{Cr}_{2} \mathrm{O}_{3}$, which formed initially, evaporates via the formation of $\mathrm{CrO}_{3}$ according to the following reaction:

$$
\mathrm{Cr}_{2} \mathrm{O}_{3}+\frac{3}{2} \mathrm{O}_{2}(\mathrm{~g}) \rightarrow 2 \mathrm{CrO}_{3}(\mathrm{~g}) \uparrow
$$

This reaction is significant above $1000^{\circ} \mathrm{C}$ and thus no $\mathrm{Cr}_{2} \mathrm{O}_{3}$ is detected on any of these alloys after extended oxidation. Some $\mathrm{NiCr}_{2} \mathrm{O}_{4}$ is formed by the solid-state reaction of $\mathrm{Cr}_{2} \mathrm{O}_{3}$ and $\mathrm{NiO}$.

Spalled oxide from $\mathrm{Ni}-10 \mathrm{Cr}-5 \mathrm{Al}-0.5 \mathrm{Y}$ oxidized at $1200^{\circ} \mathrm{C}$ for four days reveals the presence of $Y A G$ particles in the detached $\alpha-A_{2} O_{3}$ layer. After spalling had taken place, the substrate showed some $Y A G$ and $\mathrm{YAlO}_{3}$ particles in the $\alpha-\mathrm{Al}_{2} \mathrm{O}_{3}$ layer still attached to the alloy. The structure of oxide scales formed on $\mathrm{Ni}-10 \mathrm{Cr}-5 \mathrm{Al}-0.5 \mathrm{Y}$ and $\mathrm{Ni}-10 \mathrm{Cr}-5 \mathrm{Al}-1 \mathrm{Th}$ is shown in Figs. 16 and 17, respectively. At 1200 and $1150^{\circ} \mathrm{C}$, an outer scale of $\mathrm{NiAl}_{2} \mathrm{O}_{4}$ and an inner scale of $\alpha-\mathrm{Al}_{2} \mathrm{O}_{3}$ formed. At 11.00 and $1000^{\circ} \mathrm{C}$, some unreacted $\mathrm{NiO}$ formed the outermost layer, and thus a three-layer scale was observed. These results are in agreement with the $X$-ray diffraction data in Table I.

The surface morphology of the structure of the spalled oxide on $\mathrm{Ni}-10 \mathrm{Cr}-5 \mathrm{Al}$ after $30 \mathrm{~min}$. exposure at $1200^{\circ} \mathrm{C}$ is shown in Fig. 18. The oxide islands remaining on the surface were characterized by the electron microprobe and were found to be $\alpha-\mathrm{Al}_{2} \mathrm{O}_{3}$ along with some small areas of $\mathrm{NiAl}_{2} \mathrm{O}_{4}$. 


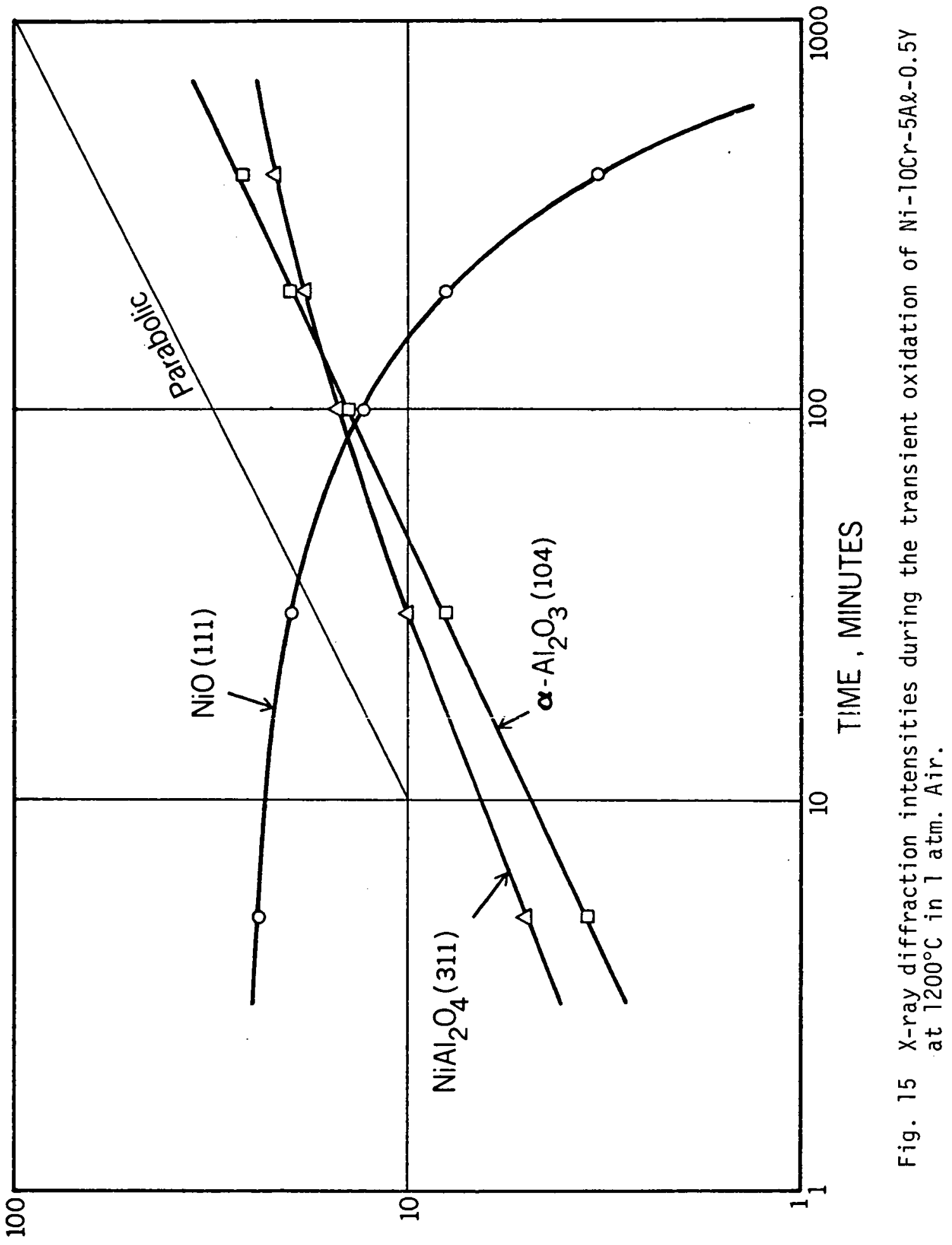

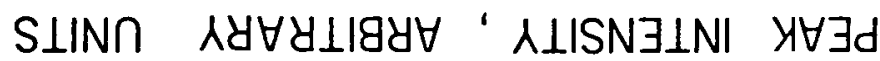



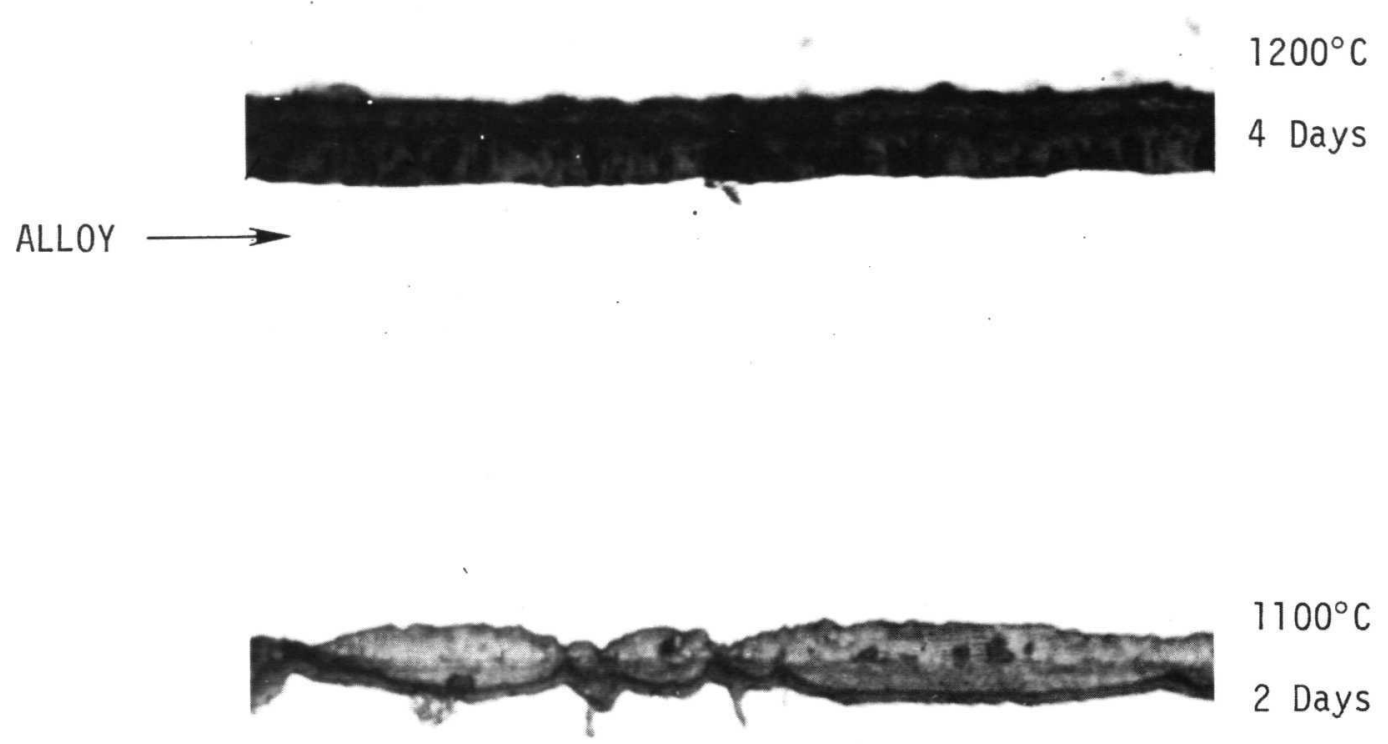

ALLOY $\longrightarrow$

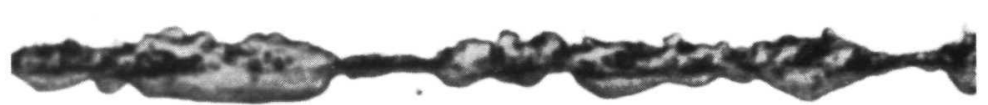

$1000^{\circ} \mathrm{C}$

2 Days

ALLOY $\longrightarrow$

Fig. 16 Structure of scales formed on $\mathrm{Ni}-10 \mathrm{C} r-5 \mathrm{Al}-0.5 \mathrm{Y}$ at various temperatures. 1000X 


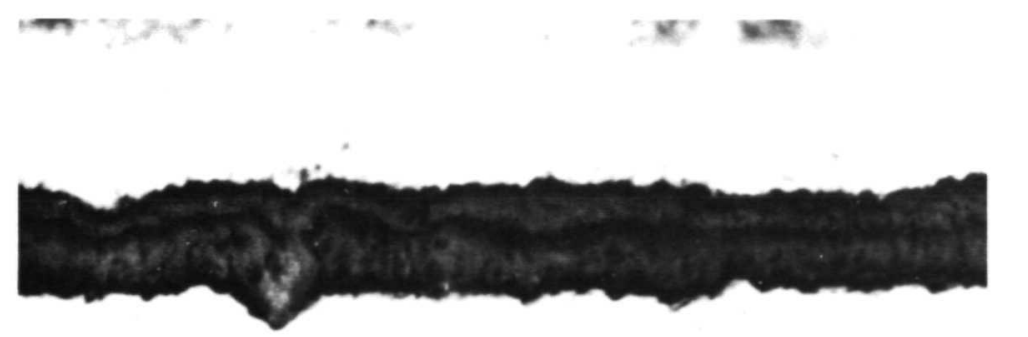

\section{$1200^{\circ} \mathrm{C}$}

ALLOY $\rightarrow$

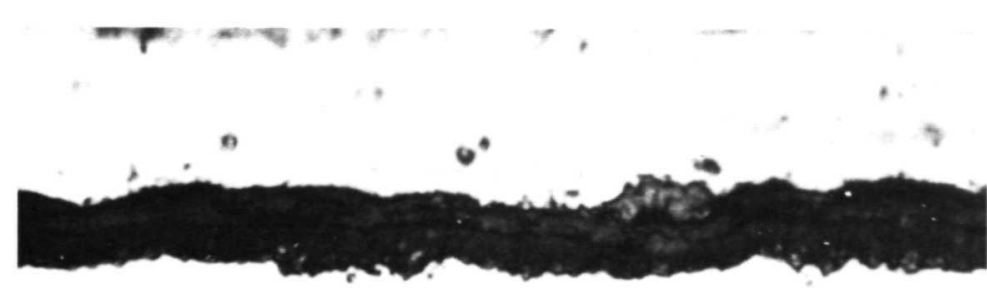

$1150^{\circ} \mathrm{C}$

ALLOY $-\longrightarrow$
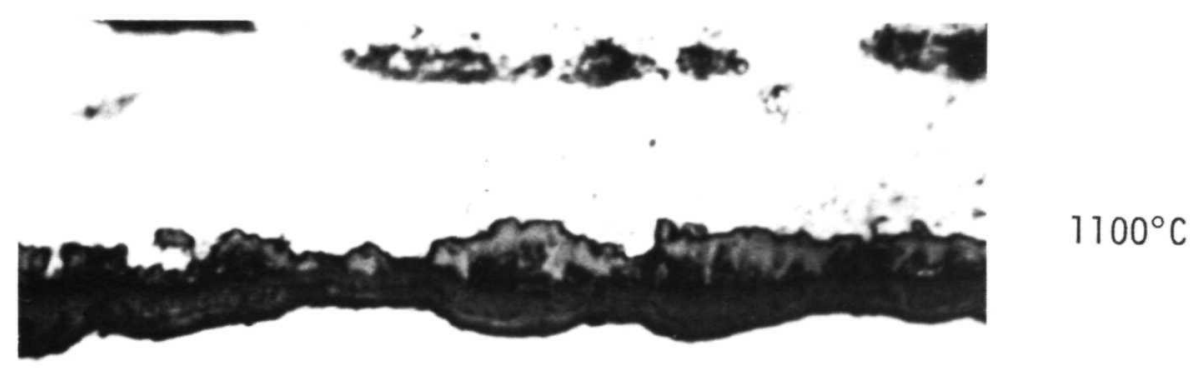

ALLOY $\longrightarrow$

Fig. 17 Structure of scales formed on $\mathrm{Ni}-10 \mathrm{Cr}-5 \mathrm{Al}-\mathrm{Th}$ oxidized for 2 days at various temperatures. 1400X 


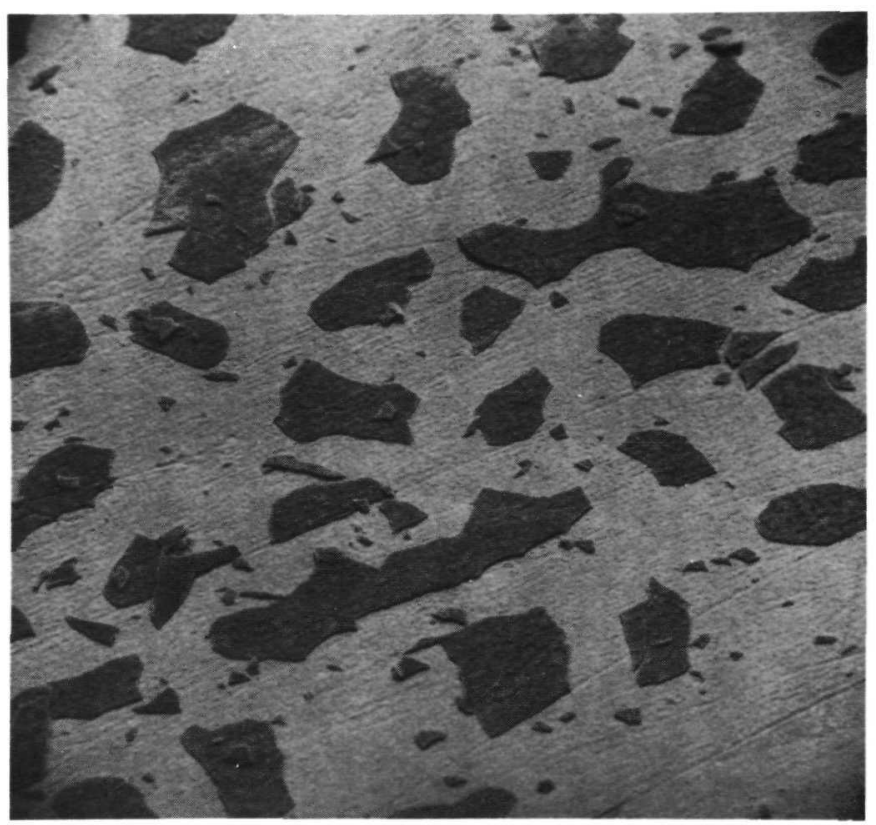

Fig. 18 Scanning electron micrograph showing spalled oxide on $\mathrm{Ni}-10 \mathrm{Cr}-5 \mathrm{Al}$ after 30 minutes at $1200^{\circ} \mathrm{C}$. 165X 
A sample of $\mathrm{Ni}-10 \mathrm{Cr}-5 \mathrm{Al}-1 \mathrm{Th}$ was immersed directly at $1200^{\circ} \mathrm{C}$ for one week in air. Very limited spalling of the oxide occurred upon cooling. A typical spalled area is shown in an optical micrograph in Fig. 19. The $\mathrm{ThO}_{2}$ particles can be seen embedded on the surface of the substrate, below the outer oxide layer. Some $\mathrm{Th}_{2}$ particles also appear to have been pulled out, along with the spalled oxide. The same area was also examined with the scanning electron microscope, as shown in Fig. 20. The thoria particles were about $20 \mu \mathrm{m}$ in diameter.

The amount of spalling on the $Y$-containing alloy was much less than on the base alloy, Ni-10Cr-5Al, after one week of oxidation at $1200^{\circ} \mathrm{C}$, as noted in the scanning electron micrographs in Fig. 21. No massive, detached oxide layers were obtained during cooling as in the case of the base alloy. The dark network in Fig. 21-a represents areas from which oxide spalled and overlaps many grains of the alloy. Fig. 21-b shows the unspalled region in which the substrate grain boundaries are apparent due to the existence there of $\mathrm{Y}_{3} \mathrm{Al}_{5}{ }^{0} 12$. A higher magnification scanning electron micrograph from another sample (oxidized $100 \mathrm{hrs}$. at $1200^{\circ} \mathrm{C}$ ) is shown in Fig. 22 in which it can be seen that a small amount of YAG existed within the grains and was still attached to the substrate, even though some YAG particles had fractured and were lost with the spalled oxide. Some YAG particles and some holes, from which some particles spalled, were also detected within the grains. The substrate surface, in general, was observed to be free of voids even at very high magnifications.

The presence of YAG particles in the grain boundaries was due to the high yttrium content of the substrate grain boundaries which in turn was due to the localization of $\mathrm{Ni}-\mathrm{Y}$ intermetallic compounds in the alloy grain boundaries. In order to prove this point, etched but unoxidized samples were examined by $X$-ray diffraction and the electron microprobe which revealed the presence of $\mathrm{Ni}_{9} \mathrm{Y}, \mathrm{Ni}_{5} \mathrm{Y}$, and $\mathrm{Ni}_{7} \mathrm{Y}_{2}$. The microstructure of the base alloy and the yttrium-containing quaternary is shown in Fig. 23.

The base alloy, $\mathrm{Ni}-10 \mathrm{Cr}-5 \mathrm{Al}$, showed a two-phase structure $\left(\gamma^{\prime} \gamma^{\prime}\right)$ at room temperature [Fig. 22(a)]. It is interesting to note that the addition of yttrium changed the structure of $\mathrm{Ni}-10 \mathrm{Cr}-5 \mathrm{Al}$. The $\mathrm{Ni}-\mathrm{Y}$ intermetallics formed preferentially at the grain boundaries, the excess aluminum being confined to the grains. The $\gamma$-phase consists of a primary solid solution of $\mathrm{Cr}$ and $\mathrm{Al}$ in nickel and has a face-centered cubic (FCC) structure which 

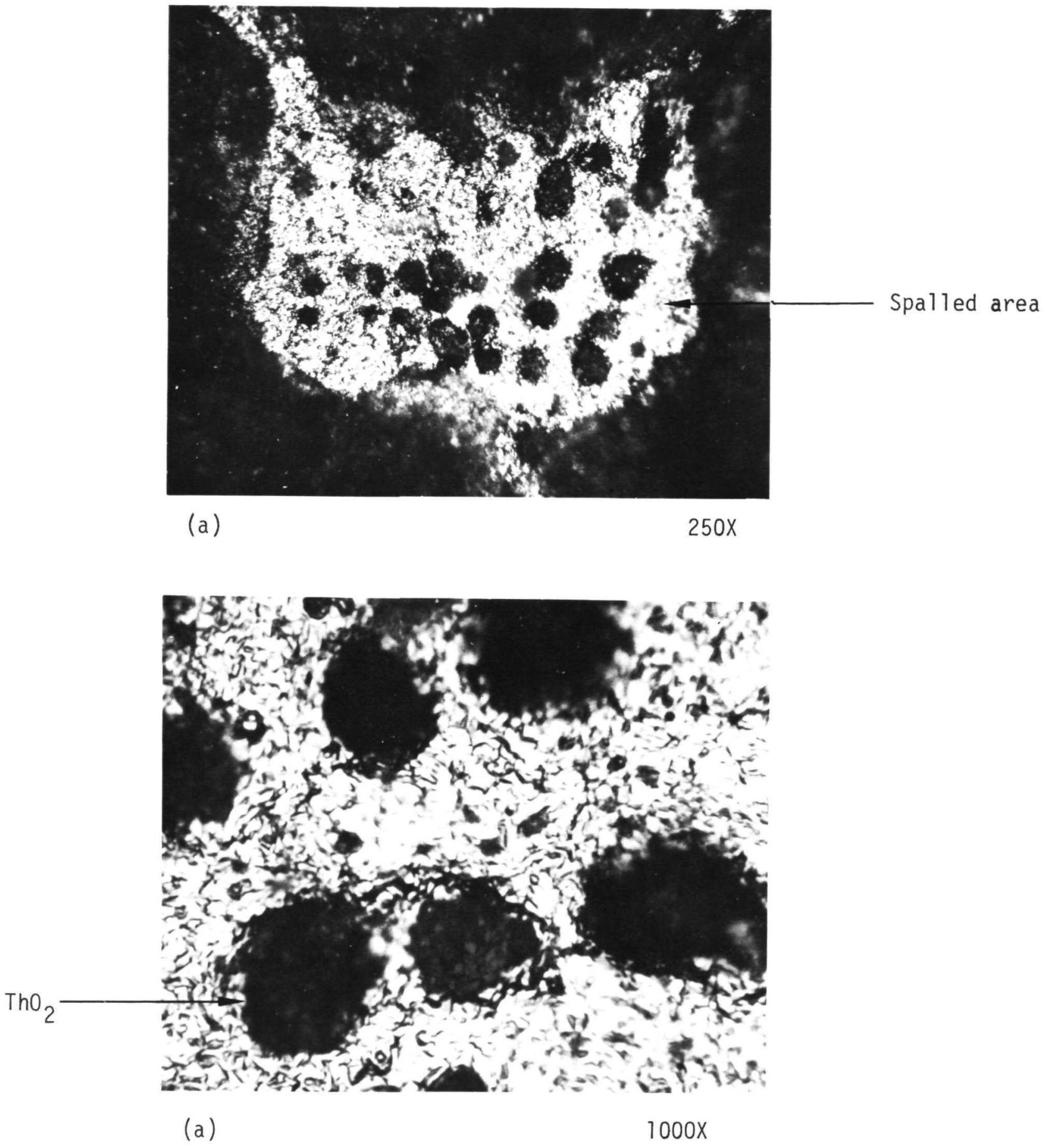

Fig. 19 Optical micrographs showing $\mathrm{ThO}_{2}$ particles on a spalled area on $\mathrm{Ni}-10 \mathrm{Cr}-5 \mathrm{Al}-1 \mathrm{Th}$ oxidized at $9200^{\circ} \mathrm{C}$ for one week. 


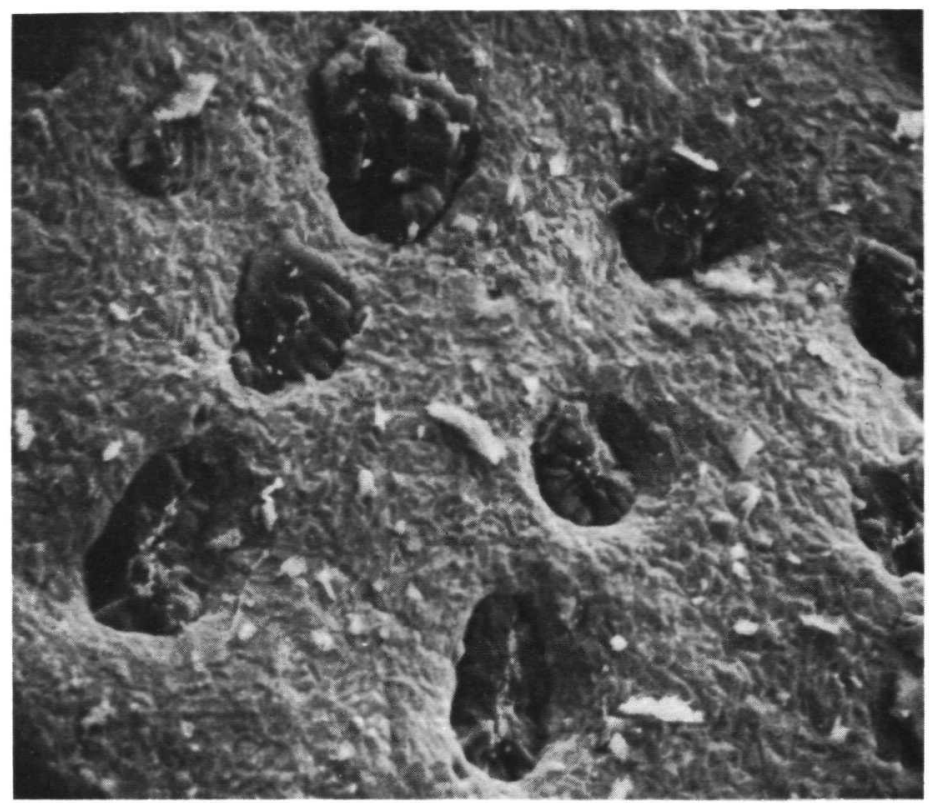

(a)

$1000 x$

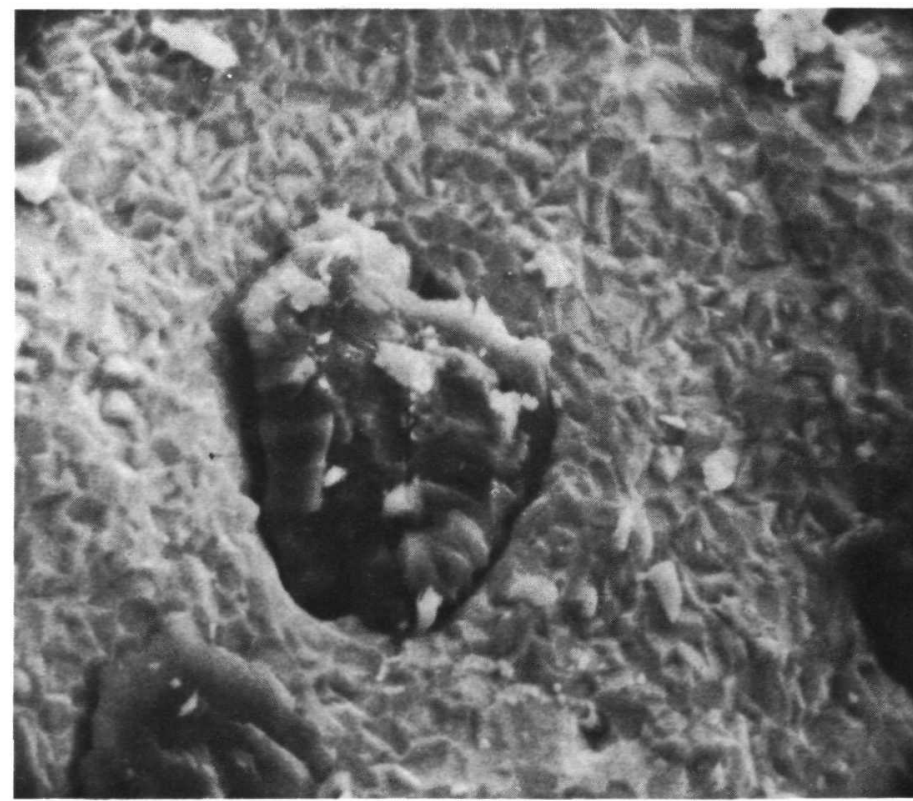

(b)

$2000 x$

Fig. 20 Scanning electron micrographs showing $\mathrm{ThO}_{2}$ particles on a spalled area on $\mathrm{Ni}-10 \mathrm{Cr}-5 \mathrm{Al}-1 \mathrm{Th}$ oxidized at $1200^{\circ} \mathrm{C}$ for one week. 


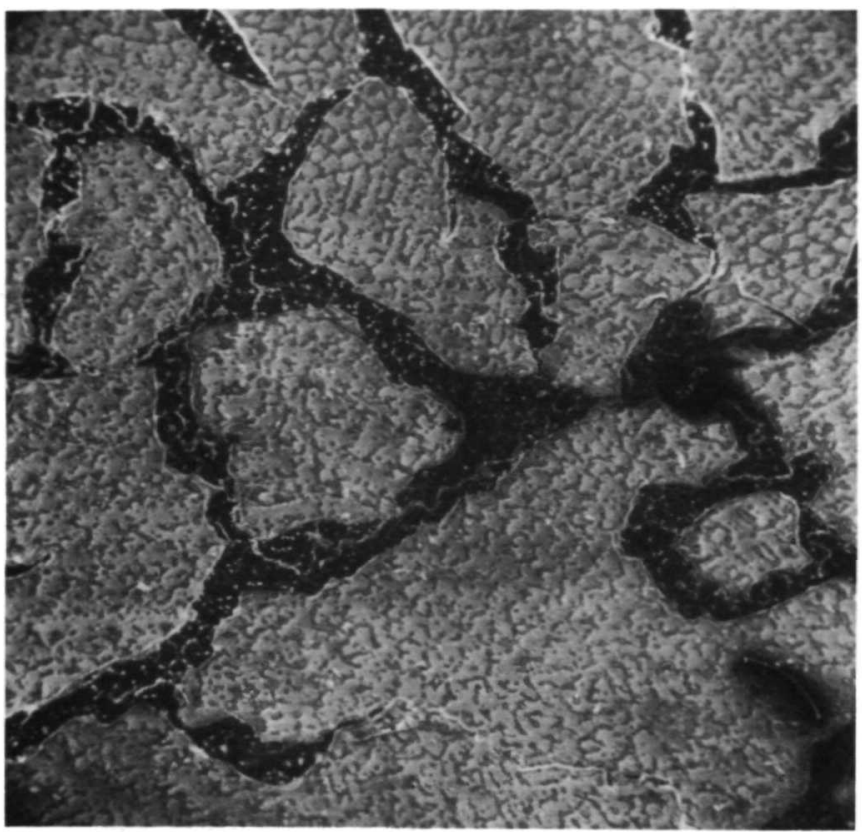

(a)

$40 \mathrm{X}$

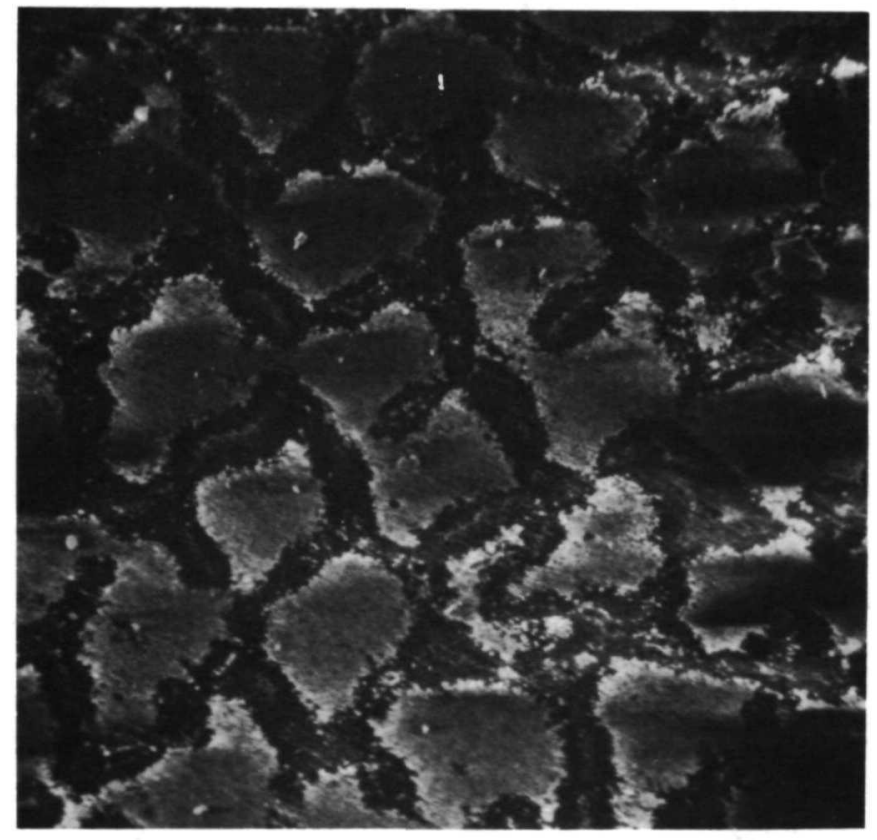

(b)

$350 x$

Fig. 21 Scanning electron micrograph showing limited spalling on $\mathrm{Ni}-\mathrm{Cr}-5 \mathrm{Al}-0.5 \mathrm{Y}$ after one week of oxidation in air at $1200^{\circ} \mathrm{C}$. (a) shows that the limited spalling overlaps many grains. (b) is an enlargement of the "unspalled" area showing the grain boundaries. The oxide formed over the substrate grains is $\mathrm{Al}_{2} \mathrm{O}_{3}$, and the oxide formed over the grain boundaries is $\mathrm{Y}_{3} \mathrm{Al}_{5}{ }^{\mathrm{O}} 12$. 


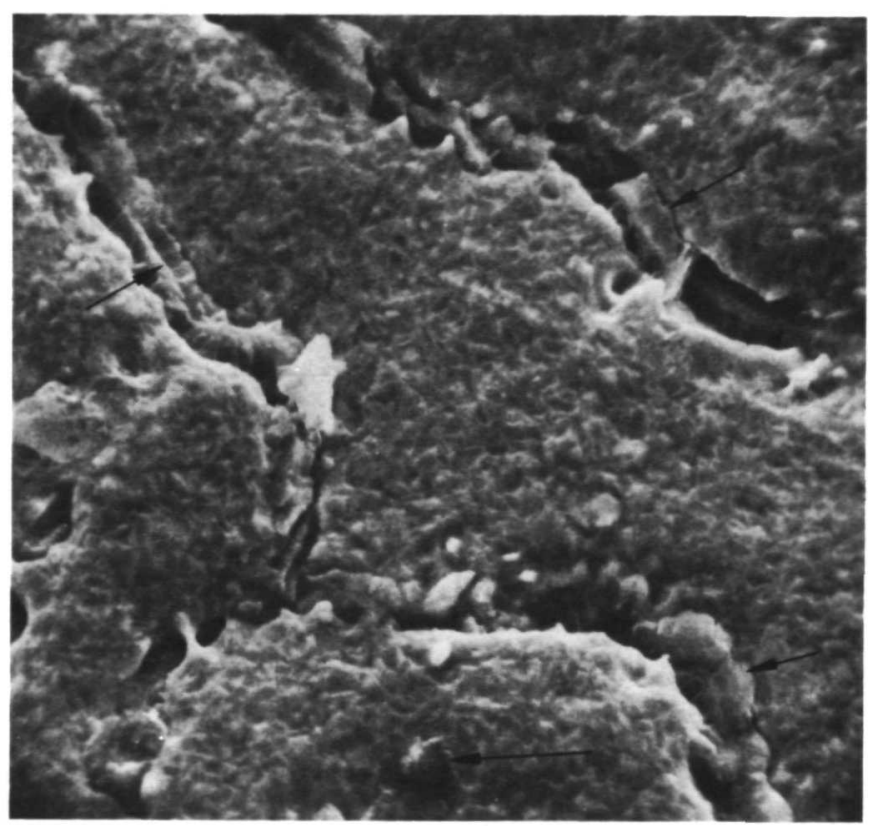

$1000 x$

Fig. 22 Scanning electron micrograph showing typical substrate surface after the oxide has spalled from $\mathrm{Ni}-10 \mathrm{Cr}-5 \mathrm{Al}-0.5 \mathrm{Y}$ after $100 \mathrm{hr}$. of oxidation in air at $1200^{\circ} \mathrm{C}$. The micrograph shows the grain boundaries from which the yttriumaluminum garnet has spalled. The arrows point to particles of yttrium-aluminum garnet which are still attached to the substrate. 


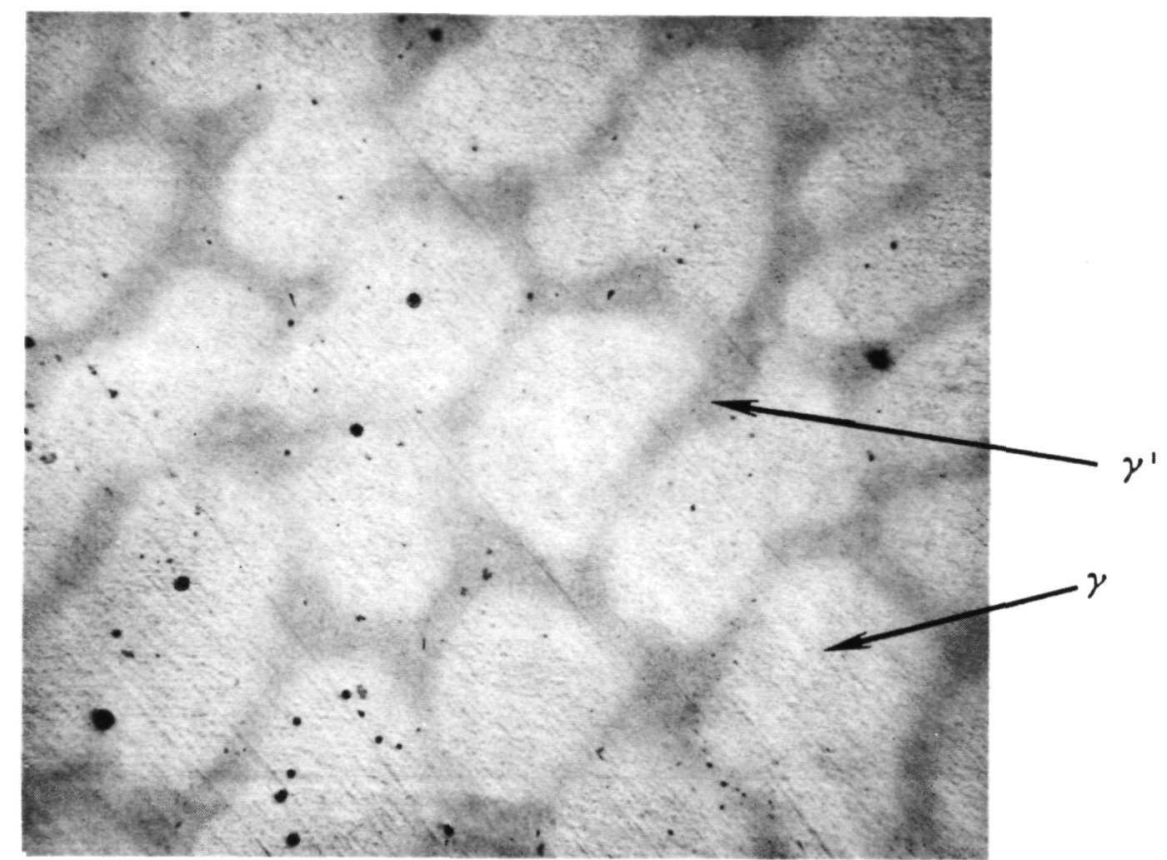

(a)

$250 x$

$$
\mathrm{Ni}-10 \mathrm{Cr}-5 \mathrm{Al}
$$

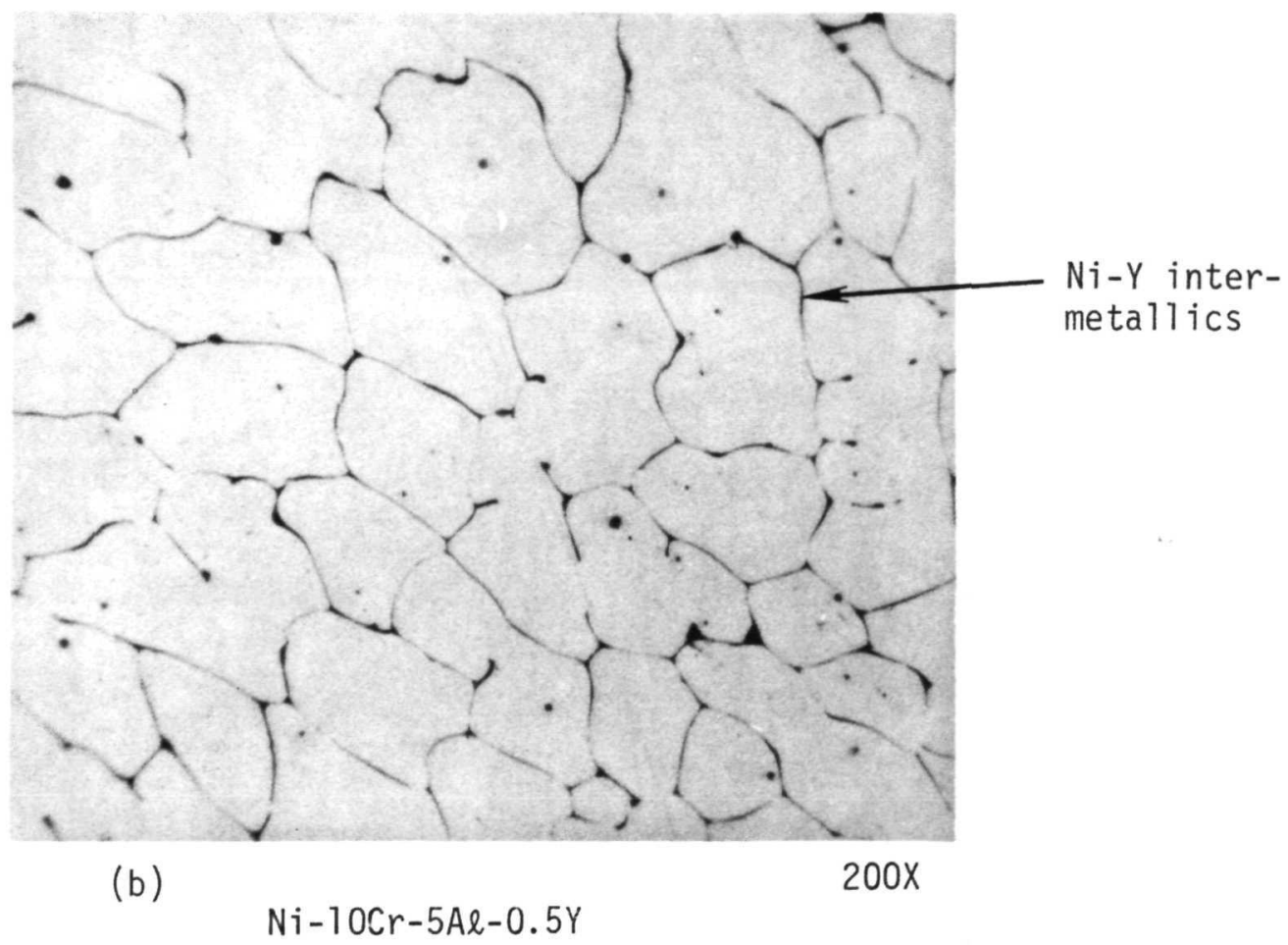

Fig. 23 Etched surface of unoxidized alloys. 
can be ordered in the neighborhood of $\mathrm{Ni}_{3} \mathrm{Cr}$ below $540^{\circ} \mathrm{C}$. (9) The $\gamma$-phase is based on the structure of $\mathrm{Ni}_{3} \mathrm{Al}$, which has an ordered FCC lattice in which nickel atoms occupy the cube faces and aluminum and chromium atoms occupy the cube corners. $(10)$

The alloys containing 0.5 and 1 w/o thorium did not contain intermetallics, however, a small amount of $\mathrm{ThO}_{2}$ was detected in the surface layers of vacuum-annealed and unoxidized alloys. The microstructure did not reveal any grain boundary precipitates.

As described earlier, the oxide film on $\mathrm{Ni}-10 \mathrm{Cr}-5 \mathrm{Al}$, without the additions of yttrium or thorium, tended to be non-adrierent. A patch of

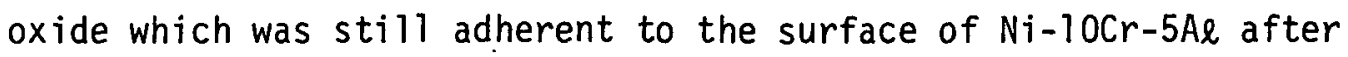
$24 \mathrm{hrs}$. of oxidation at $1200^{\circ} \mathrm{C}$ is shown in Fig. 24 . An enlarged view [Fig. 24(b)] shows that there were areas over which the oxide had partially separated from the substrate.

A piece of partially detached oxide scale from $\mathrm{Ni}-10 \mathrm{Cr}-5 \mathrm{Al}$ after $50 \mathrm{hrs}$. oxidation at $1200^{\circ} \mathrm{C}$ was examined at an angle of $75^{\circ}$ in crosssection. The scanning micrograph is shown in Fig. 25 and shows a string of voids formed at the bottom of the oxide at the oxide/metal interface. These voids cause a loss of contact of the oxide, which eventually leads to spallation of the oxide. These voids were also observed on the underside of the detached oxide, i.e., at the oxide/metal interface, as shown in Fig. 26. The oxide showed a granular structure and the voids were uniformly distributed throughout the oxide at the oxide/metal interface. 


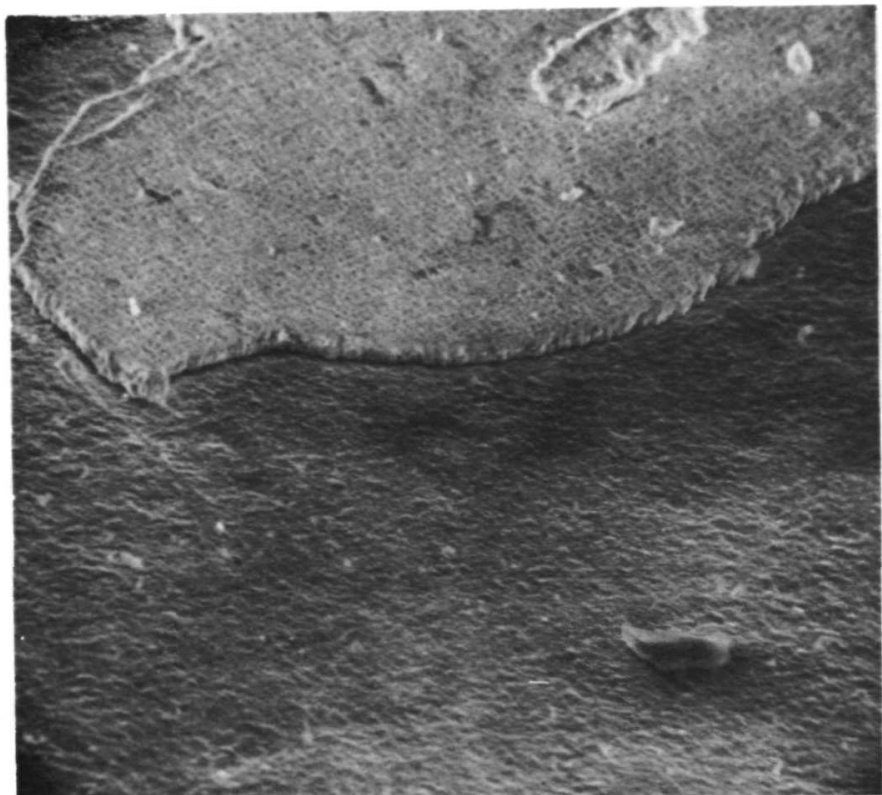

(a)

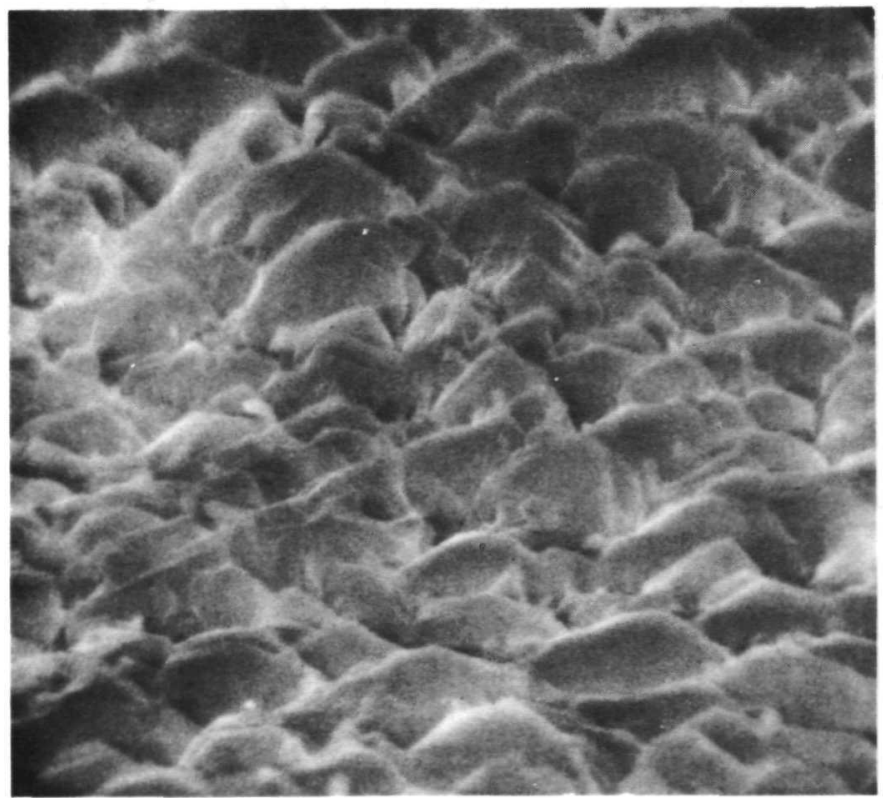

(c)

$7500 x$

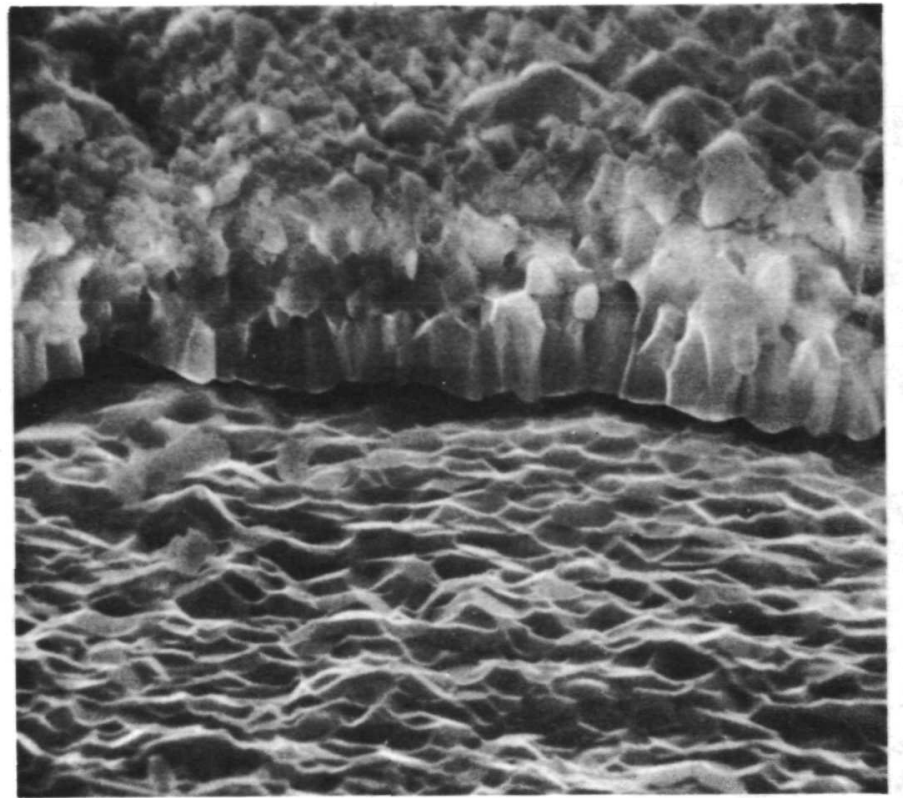

(b)

$3500 x$

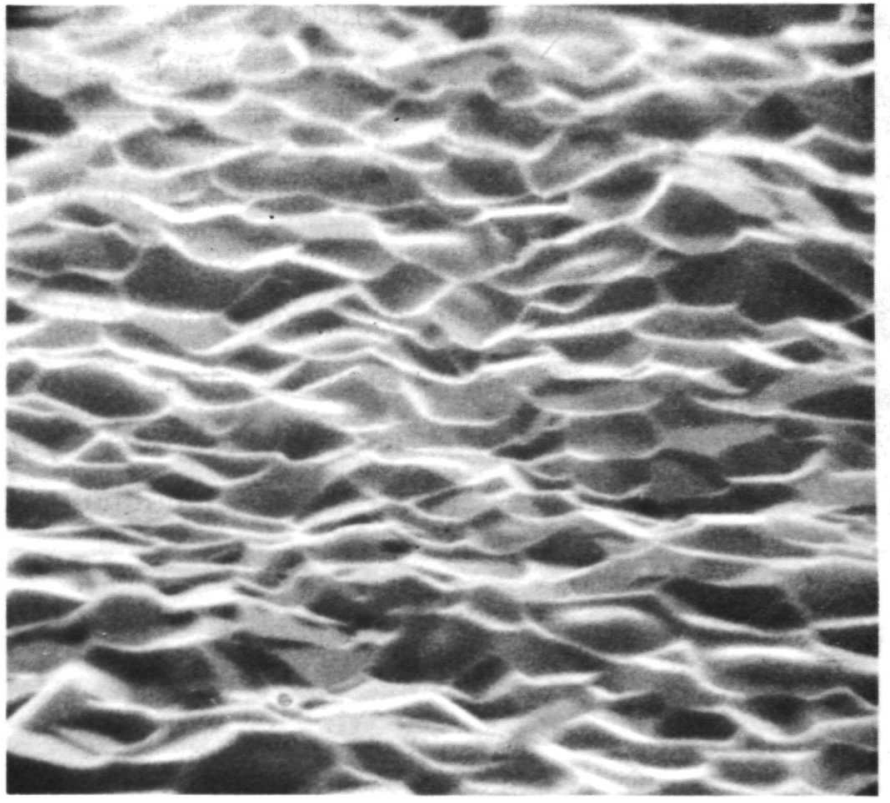

(d)

$7500 x$

Fig. 24 Scanning electron micrographs of the partially adherent oxide scale formed on $\mathrm{Ni}-10 \mathrm{Cr}-5 \mathrm{Al}$ after $24 \mathrm{hr}$. of oxidation in air at $1200^{\circ} \mathrm{C}$. In (a) a patch of oxide is shown which did not spall on cooling. Also, the columnar grains of $\alpha-\mathrm{Al}_{2} \mathrm{O}_{3}$ can be seen next to the substrate. (b) is an enlarged view $\mathrm{f}^{3}(\mathrm{a})$. (c) and (d) show a more enlarged view of the oxide surface and the substrate surface, respectively. All the micrographs are taken at $75^{\circ}$ tilt. 


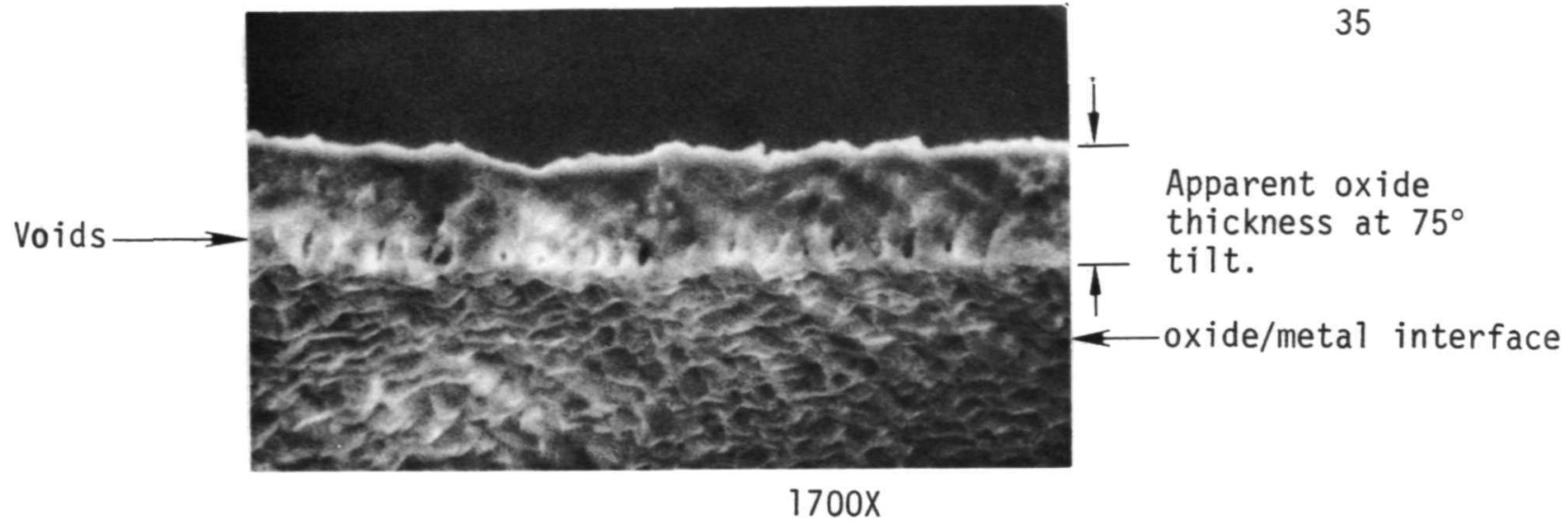

Fig. 25 Scanning electron micrograph of partially spalled $\mathrm{Al}_{2} \mathrm{O}_{3}$ film after 50 hrs. oxidation of $\mathrm{Ni}-10 \mathrm{Cr}-5 \mathrm{Al}$ at $1200^{\circ} \mathrm{C}$, observed ${ }^{2} \mathrm{t}$ an angle of $75^{\circ}$. Typical morphology of the oxide/metal interface is shown at the bottom of the micrograph. A string of voids can be observed at the oxide/metal interface.

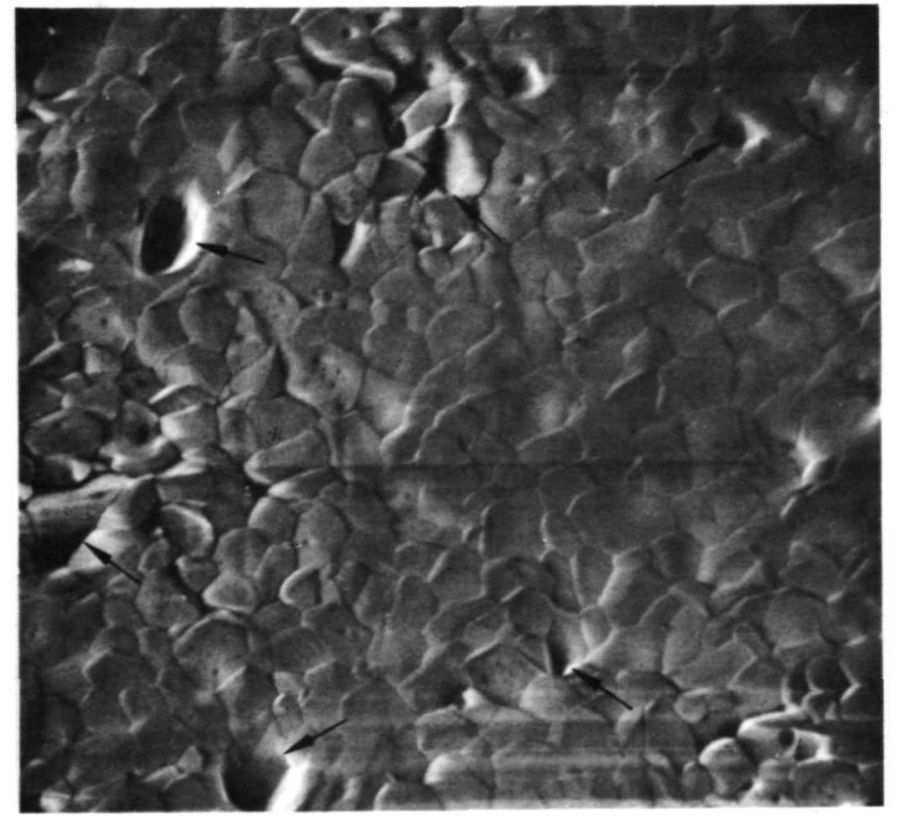

$3500 X$

Fig. 26 Scanning electron micrograph of the bottom of the non-adherent oxide at the oxide/metal interface, detached from $\mathrm{Ni}-10 \mathrm{Cr}-5 \mathrm{Al}$ after $50 \mathrm{hrs}$. oxidation at $1200^{\circ} \mathrm{C}$. The granular appearance of the oxide can be seen. The arrows point at the voids which are always observed. 


\section{DISCUSSION}

The oxidation mechanism of $\mathrm{Ni}-\mathrm{Cr}$-Al ternary alloys is complex and depends upon the composition of the alloy as well as the time, oxygen pressure, and temperature of oxidation. During the preliminary experiments on various $\mathrm{Ni}-\mathrm{Cr}-\mathrm{Al}$ ternary alloys, it was found that a minimum aluminum content of about $5 \%$ was required to form a continuous film of $\mathrm{Al}_{2} \mathrm{O}_{3}$ which was by far more protective than a film of $\mathrm{Cr}_{2} \mathrm{O}_{3}$. However, chromium seems to affect the minimum aluminum content as may be noted from the erratic results obtained on the $\mathrm{Ni}-5 \mathrm{Cr}-5 \mathrm{Al}$ alloy. A higher chromium content, e.g., 10\%, while maintaining the same aluminum content, i.e., 5\%, eliminates this problem. Thus, all the studies were made on alloys based on the $\mathrm{Ni}-10 \mathrm{Cr}-5 \mathrm{Al}$ composition. The only alloy that did not spall was the $\mathrm{Ni}-12 \mathrm{Cr}-3 \mathrm{Al}$ alloy, which is actually a $\mathrm{Cr}_{2} \mathrm{O}_{3}$ scale former. Oxidation of $\mathrm{Ni}-10 \mathrm{Cr}-5 \mathrm{Al}$

The oxidation mechanism of the $\mathrm{Ni}-10 \mathrm{Cr}-5 \mathrm{Al}$ alloy can be described as follows. Upon exposure to air at temperature, NiO nucleated and grew very rapidly by outward nickel diffusion. As NiO formed, the substrate become richer in $\mathrm{Al}$ and $\mathrm{Cr}$ and subsequently $\alpha-\mathrm{Al}_{2} \mathrm{O}_{3}$ and/or $\mathrm{Cr}_{2} \mathrm{O}_{3}$ formed. A very small amount of $\mathrm{NiCr}_{2} \mathrm{O}_{4}$ was also detected initially. However, because $\mathrm{Cr}_{2} \mathrm{O}_{3}$ oxidizes to gaseous $\mathrm{CrO}_{3}$ at very high temperatures $\left(1100-1200^{\circ} \mathrm{C}\right), \mathrm{Cr}_{2} \mathrm{O}_{3}$ was lost if it was exposed to the oxidant, and thus it was not detected at a later stage. Once a sufficiently thick layer of $\alpha-\mathrm{Al}_{2} \mathrm{O}_{3}$ had formed, the outward diffusion of nickel was inhibited and further formation of $\mathrm{NiO}$ ceased. The $\mathrm{NiO}$ and $\alpha-\mathrm{Al}_{2} \mathrm{O}_{3}$ formed $\mathrm{NiAl}_{2} \mathrm{O}_{4}$ via a solid-state reaction. After extended times, no NiO was detected, and the oxide layer consisted of an outer $\mathrm{NiAl}_{2} \mathrm{O}_{4}$ and an inner $\alpha-\mathrm{Al}_{2} \mathrm{O}_{3}$ layer.

The Arrhenius plot for $\mathrm{Ni}-10 \mathrm{Cr}-5 \mathrm{Al}$ shows a continuously decreasing slope (Fig. 13). Since more than one oxide was present, no physical interpretation can be associated with the activation energies obtained from the Arrhenius plots. However, the amount of $\mathrm{\alpha}_{-} \mathrm{Al}_{2} \mathrm{O}_{3}$ and $\mathrm{NiAl}_{2} \mathrm{O}_{4}$ increased while the amount of $\mathrm{NiO}$ decreased with an increase in temperature and vice-versa (Table I). However, the activation energy obtained for the 
growth of $\alpha-\mathrm{Al}_{2} \mathrm{O}_{3}$ by quantitative $X$-ray diffraction, $50 \mathrm{Kcal} / \mathrm{mol}$, is valid and can give an insight into the oxidation mechanism. 0ishi and Kingery (11) obtained an activation energy of $152 \mathrm{Kcal} / \mathrm{mol}$ for the diffusion of oxygen in $\alpha-\mathrm{Al}_{2} \mathrm{O}_{3}$ above $1600^{\circ} \mathrm{C}$, while below $1600^{\circ} \mathrm{C}$ the activation energy was only $57.6 \mathrm{Kcal} / \mathrm{mol}$. This change was attributed to the fact that at lower temperatures the oxygen diffusion rate in $\alpha-\mathrm{Al}_{2} \mathrm{O}_{3}$ is structure sensitive, i.e., oxygen diffusion along the grain boundaries predominates. Thus, the observed activation energy value of $50 \mathrm{Kcal} / \mathrm{mol}$ for the growth of the alumina scale suggests that oxidation occurred by oxygen diffusion in the alumina grain boundaries. Because the oxide scale consists of an outer $\mathrm{NiAl}_{2} \mathrm{O}_{4}$ and an inner $\alpha-\mathrm{Al}_{2} \mathrm{O}_{3}$ layer at $1200^{\circ} \mathrm{C}$, rapid oxygen diffusion or permeation through $\mathrm{NiAl}_{2} \mathrm{O}_{4}$ will cause the oxidation kinetics to be controlled by oxygen diffusion through the inner $\alpha-\mathrm{Al}_{2} \mathrm{O}_{3}$ layer. The growth of the $\alpha-\mathrm{Al}_{2} \mathrm{O}_{3}$ layer was parabolic (Fig. 15), which is attributable to a diffusion-controlled process, thus this hypothesis is reasonable.

Effect of Yttrium

There was little change in the oxidation kinetics upon the addition of yttrium to the alumina-former alloy ( $\mathrm{Ni}-10 \mathrm{Cr}-5 \mathrm{Al})$; however, a large decrease in the oxidation rate occurred by the addition of yttrium to the $\mathrm{Cr}_{2} \mathrm{O}_{3}$ former alloy (Ni-12Cr-3Al). This effect may be due to the formation of mixed yttrium-aluminum double oxides $\left(\mathrm{YAlO}_{3}\right.$ aric $\left.\mathrm{Y}_{3} \mathrm{Al}_{5} \mathrm{O}_{12}\right)$ which were detected in small amounts by X-ray diffraction. The double oxides were present as discrete particles (mostly at the grain boundaries) and not as a continuous layer. These particles may provide a small, but additional barrier to the diffusing species and thereby reduce the oxidation rate. Such oxides were also detected on the alumina-former alloys. It appears that the protectiveness offered by the mixed oxides is comparable to that offered by $\mathrm{Al}_{2} \mathrm{O}_{3}$.

The activation energy obtained for the oxidation of $\mathrm{Ni}-10 \mathrm{Cr}-5 \mathrm{Al}-0.5 \mathrm{Y}$ was the same $(50 \mathrm{Kcal} / \mathrm{mol})$ as for the base alloy, $\mathrm{Ni}-10 \mathrm{Cr}-5 \mathrm{Al}$ (Fig. 13) which indicates that the oxidation mechanism was not changed appreciably by the addition of yttrium. However, the amount of $\mathrm{NiAl}_{2} \mathrm{O}_{4}$ formed on the alloy, containing yttrium was greater than on the alloy without yttrium. The enhanced formation of $\mathrm{NiAl}_{2} \mathrm{O}_{4}$ during the oxidation of yttrium-containing 
alloys can be explained as follows: The yttrium exists primarily as $\mathrm{Ni}-\mathrm{Y}$ intermetallic compounds $\left(\mathrm{Ni}_{9} \mathrm{Y}, \mathrm{Ni}_{5} \mathrm{Y}\right.$, and $\left.\mathrm{Ni}_{7} \mathrm{Y}_{2}\right)$ in the grain boundaries of the alloy. A small amount also exists within the grains. 0xidation of the intermetallic phases results in the formation of $\mathrm{Y}_{2} \mathrm{O}_{3}$ and metallic nickel, which subsequently reacts to form $\mathrm{NiO}$. A further reaction occurs between the $\mathrm{NiO}$ and $\alpha-\mathrm{Al}_{2} \mathrm{O}_{3}$ to form $\mathrm{NiAl}_{2} \mathrm{O}_{4}$. The $\mathrm{Y}_{2} \mathrm{O}_{3}$ al so reacts with $\alpha-\mathrm{Al}_{2} \mathrm{O}_{3}$ to form $\mathrm{YAlO}_{3}$ initially and ultimately to form $\mathrm{Y}_{3} \mathrm{Al}_{5} \mathrm{O}_{12}$. The sequence of oxide formation in the presence of yttrium is shown in Fig. 14, and can be described by the following equations:

$$
\begin{aligned}
& 2 \mathrm{Ni}_{9} \mathrm{Y}+3 \underline{0} \rightarrow \mathrm{Y}_{2} \mathrm{O}_{3}+18 \mathrm{Ni} \\
& 2 \mathrm{Ni}_{5} \mathrm{Y}+3 \underline{0} \rightarrow \mathrm{Y}_{2} \mathrm{O}_{3}+10 \mathrm{Ni} \\
& \mathrm{Ni}_{7} \mathrm{Y}_{2}+3 \underline{0} \rightarrow \mathrm{Y}_{2} \mathrm{O}_{3}+7 \mathrm{Ni} \\
& \mathrm{Y}_{2} \mathrm{O}_{3}+\mathrm{Al}_{2} \mathrm{O}_{3} \rightarrow 2 \mathrm{YAlO}_{3} \\
& 3 \mathrm{YAlO}_{3}+\mathrm{Al}_{2} \mathrm{O}_{3} \rightarrow \mathrm{Y}_{3} \mathrm{Al}_{5} \mathrm{O}_{12} \quad \text { (Garnet Structure) }
\end{aligned}
$$

The addition of yttrium to $\mathrm{Ni}-10 \mathrm{Cr}-5 \mathrm{Al}$ caused a slight decrease in the oxidation rate. Such a reduction in the oxidation rate by the addition of $\mathrm{Y}^{3+}$ to $\mathrm{Al}_{2} \mathrm{O}_{3}$ cannot be explained by the Wagner-Hauffe theory because the valences are identical, e.g., trivalent. It is possible, however, that yttrium can increase the enthalpy of vacancy formation in $\alpha-\mathrm{Al}_{2} \mathrm{O}_{3}$ and thus reduce the oxidation rate. The reduction in the oxidation rate may also be attributed to the protectiveness of the yttriumaluminum double oxides. The addition of yttrium to alumina scale-formers virtually eliminated short-term spalling of the scale during cooling.

Effect of Thorium

The activation energy for the oxidation of both $\mathrm{Ni}-10 \mathrm{Cr}-5 \mathrm{Al}-0.5 \mathrm{Th}$ and $\mathrm{Ni}-10 \mathrm{Cr}-5 \mathrm{Al}-1 \mathrm{Th}$ was approximately $50 \mathrm{Kcal} / \mathrm{mol}$ (Fig. 13). Thus thorium had virtually no effect on the oxidation mechanism of $\mathrm{Ni}-10 \mathrm{Cr}-5 \mathrm{Al}$. However, the addition of thorium increased the oxidation rate of $\mathrm{Ni}-10 \mathrm{Cr}-5 \mathrm{Al}$ slightly. The increase in the oxidation rate by the thorium addition may be due to a doping effect, because thorium has a valency of 4 (higher than that of $\mathrm{Al)}$ and $\mathrm{Al}_{2} \mathrm{O}_{3}$ is a p-type semiconductor at $1 \mathrm{~atm}$. air. (12) If this is true, according to the Wagner-Hauffe theory of doping, $\mathrm{Th}^{4+}$ should increase the oxidation rate. 
Thorium additions of 0.5 and $1 \mathrm{w} / \mathrm{O}$ to $\mathrm{Ni}-10 \mathrm{Cr}-5 \mathrm{Al}$ al so improved the short-term oxide scale adherence. Thorium and yttrium can be expected to prove similar effects as both of them are chemically similar.

The quaternary addition of thorium formed only its own oxide, i.e., $\mathrm{ThO}_{2}$ particles; no double oxide of thorium formed, as in the case of yttrium-containing alloys.

Oxide Scale'Adherence

It has already been noted that the oxide on $\mathrm{Ni}-10 \mathrm{Cr}-5 \mathrm{Al}$ spalled readily upon cooling even after $15 \mathrm{~min}$. of oxidation at $1200^{\circ} \mathrm{C}$. Both yttrium and thorium markedly improved the short-term scale adherence. Although the long-term spalling resistance (after one week of oxidation at $1200^{\circ} \mathrm{C}$ ) was improved somewhat, e.g., the scale did not spall off completely, some spalling did occur. Thorium appears to be a better addition than yttrium in terms of oxide-scale adherence. This behavior can be attributed to the fact that thoria does not form double oxides with alumina as does yttria. There is a much greater volume expansion, resulting in mechanical stresses, when $Y A G$ forms compared to that associated with the formation of $\mathrm{ThO}_{2}$ particles. This was confirmed by the observation that the onset of spalling was associated with the appearance of the YAG particles after oxidation of the $\mathrm{Ni}-10 \mathrm{Cr}-5 \mathrm{Al}-0.5 \mathrm{Y}$ alloy at $1200^{\circ} \mathrm{C}$ in air for 200 mins. (Fig. 14), as compared with the alloy containing thorium which did not spall for about one week under the same conditions. The YAG and $\mathrm{ThO}_{2}$ particles act as stress-raisers and literally push the oxide layer away from the substrate. This results in the fracture of the oxide and subsequently causes spalling.

The tremendous improvement in the oxide-scale adherence with sma11 additions of yttrium or thorium cannot be explained on the basis of most. of the factors commonly proposed for the improvement of oxide-scale adherence, such as a reduction in the Pilling-Bedworth ratio, improved oxide-film plasticity, or a decrease in the difference between the thermal expansion coefficients of the oxide and the substrate. The "oxide-pegging" mechanism, or what is commonly known as the "key-on effect," can also be precluded since no oxide pegs were observed at the oxide/alloy interface (Figs. 16 and 17). It was therefore concluded that the presence 
of voids at the alloy/oxide interface may play an important role in spalling. A similar mechanism has been observed by Tien and Rand, (13) and Tien and Pettit ${ }^{(14)}$ on $\mathrm{Ni}-12 \mathrm{Al}$ and $\mathrm{Fe}-25 \mathrm{Cr}-4 \mathrm{Al}$, respectiveiy, both of the alloys being alumina formers at $1200^{\circ} \mathrm{C}$.

Voids were observed at the alloy/oxide interface as shown by the scanning electron micrographs in Figs. 25 and 26 on $\mathrm{Ni}-10 \mathrm{Cr}-5 \mathrm{Al}$ after oxidation at $1200^{\circ} \mathrm{C}$ for $50 \mathrm{hrs}$. In contrast, no voids at the alloy/oxide interface were observed on the alloys containing thorium and yttrium, Figs. 20 and 22, respectively. Based upon these observations a model is proposed similar to that of Tien and Rand, (13) and Tien and Pettit, (14) which explains the improvement of the oxide-scale adherence on alloys containing yttrium and thorium.

As described earlier, for the $\mathrm{Ni}-10 \mathrm{Cr}-5 \mathrm{Al}$ alloy, once the outer $\mathrm{NiAl}_{2} \mathrm{O}_{4}$ layer is separated from the substrate by the intervening $\alpha-\mathrm{Al}_{2} \mathrm{O}_{3}$ layer, the $\alpha-\mathrm{Al}_{2} \mathrm{O}_{3}$ scale grows by inward diffusion of oxygen along the grain boundaries. This mechanism of oxidation was suggested on the basis of the value of the activation energy of $50 \mathrm{Kcal} / \mathrm{mol}$. The voids observed at the alloy/oxide interface are Kirkendall voids which form first in the substrate due to outward nickel diffusion and thereafter due to the selective oxidation of aluminum. The vacancies are formed by unequal diffusion of Al atoms towards the external oxide scale and back diffusion of $\mathrm{Ni}$ and $\mathrm{Cr}$ atoms in the opposite direction. Initially the voids are formed within the substrate near the alloy/oxide interface, but eventually are incorporated into the alloy/oxide interface because inward growth of the $\alpha-\mathrm{Al}_{2} \mathrm{O}_{3}$ occurs consuming the substrate. Furthermore, since the diffusion of aluminum to the oxide and diffusion of other atoms into the alloy takes place from the void/substrate interface, the voids also move inwards along with the oxide/alloy interface, and thus the voids are never completely enveloped within the oxide scale. The voids also keep on growing by the precipitation of additional vacancies as the oxidation process continues. The failure of the scale occurs at the alloy/oxide interface due to the presence of a large number of these voids which act as stress concentration sites.

Rare-earth oxide particles such as $\mathrm{Y}_{2} \mathrm{O}_{3}, \mathrm{Y}_{3} \mathrm{Al}_{5} \mathrm{O}_{12}$, and $\mathrm{ThO}_{2}$ act as vacancy sinks at sites away from the alloy/oxide interface, thus preventing 
void formation and improving the oxide-scale adherence. Yttrium and thorium can also provide vacancy-sinks by forming complexes with the vacancies. (14) Since the atoms of $Y$ and Th are large as compared to the base alloy atoms, i.e., $\mathrm{Ni}, \mathrm{Cr}$, and $\mathrm{Al}$, the dilatational strain energy associated with the larger atoms can be decreased if these atoms form atom-vacancy complexes with the excess vacancies. This "vacancy-sink" mechanism can explain why none or very few voids are observed at the alloy/oxide interface in the presence of yttrium and thorium, thus improving the oxide-scale adherence. 


\section{REFERENCES}

1. Douglass, D.L., Proc. 1971 Conference of Society of Aerospace Materials and Process Engineers 16 (1971) 1.

2. Douglass, D.L. and Armijo, J.S., Oxidation of Metals $\underline{2}$ (1970) 207.

3. Pettit; F.S., Trans. AIME 239 (1967) 1296.

4. Wallwork, G.R. and Hed, A.Z., Oxidation of Metals $\underline{3}$ (1971) 171.

5. Kvernes, I. and Kofstad, P., "Studies on the Behavior of Nickel-Base Superalloys at High Temperatures," Tech. Report AFML-TR-70-103, July 1970.

6. Scott, F.H. and Wood, G.C., Corr. Science 11 (1971) 799.

7. Kosak, R, Ph.D. Thesis, The Ohio State University (1969).

8. Santoro, G.J., Deadmore, D.L., and Lowe11, C.E., "Oxidation of Alloys in the $\mathrm{Ni}-\mathrm{Al}$ System with Third Element Additions of $\mathrm{Cr}, \mathrm{Si}$, and Ti at $1100^{\circ} \mathrm{C}, "$ NASA-TN-D-6414, JuTy 1971.

9. Taylor, A., and Hinton, K.G., J. Inst. of Metals 81 (1952-53) 169.

10. Taylor, A., and Floyd, R.W., J. Inst. of Metals 81 (1952-53) 451.

11. Oishi, Y., and Kingery, Jr., W.D., J. Chem. Physics $\underline{38}$ (1960) 480.

12. Pappis, J., and Kingery, W.D., J. Amer. Ceramic Soc. 44 (1961) 459.

13. Tien, J.K., and Rand, W.H., Scripta Met. $\underline{6}$ (1972) 55.

14. Tien, J.K. and Pettit, F.S., Met. Trans. $\underline{3}$ (1972) 1587. 
Page Intentionally Left Blank 
"The aeronautical and space activities of the United States shall be conducted so as to contribute . . . to the expansion of human knowledge of phenomena in the atmosphere and space. The Administration shall provide for the widest practicable and appropriate dissemination of information concerning its activities and the results thereof."

\section{NASA SCIENTIFIC AND TECHNICAL PUBLICATIONS}

TECHNICAL REPORTS: Scientific and technical information considered important, complete, and a lasting contribution to existing knowledge.

TECHNICAL NOTES: Information less broad in scope but nevertheless of importance as a contribution to existing knowledge.

TECHNICAL MEMORANDUMS:

Information receiving limited distribution because of preliminary data, security classification, or other reasons. Also includes conference proceedings with either limited or unlimited distribution.

CONTRACTOR REPORTS: Scientific and technical information generated under a NASA contract or grant and considered an important contribution to existing knowledge.
TECHNICAL TRANSLATIONS: Information published in a foreign language considered to merit NASA distribution in English.

SPECIAL PUBLICATIONS: Information derived from or of value to NASA activities. Publications include final reports of major projects, monographs, data compilations, handbooks, sourcebooks, and special bibliographies.

\section{TECHNOLOGY UTILIZATION}

PUBLICATIONS: Information on technology used by NASA that may be of particular interest in commercial and other non-aerospace applications. Publications include Tech Briefs, Technology Utilization Reports and Technology Surveys.

Details on the availability of these publications may be obtained from:

SCIENTIFIC AND TECHNICAL INFORMATION OFFICE 